\title{
Tumor Microenvironment-Derived Metabolites: A Guide to Find New Metabolic Therapeutic Targets and Biomarkers
}

\author{
Juan C. García-Cañaveras ${ }^{1, *(D)}$ and Agustín Lahoz ${ }^{1,2, *(\mathbb{D})}$ \\ 1 Biomarkers and Precision Medicine Unit, Medical Research Institute-Hospital La Fe, \\ Av. Fernando Abril Martorell 106, 46026 Valencia, Spain \\ 2 Analytical Unit, Medical Research Institute-Hospital La Fe, Av. Fernando Abril Martorell 106, \\ 46026 Valencia, Spain \\ * Correspondence: juancarlos_garcia@iislafe.es (J.C.G.-C.); agustin.lahoz@uv.es (A.L.); \\ Tel.: +34-961246673 (J.C.G.-C.); +34-616535288 (A.L.)
}

check for updates

Citation: García-Cañaveras, J.C.;

Lahoz, A. Tumor MicroenvironmentDerived Metabolites: A Guide to Find New Metabolic Therapeutic Targets and Biomarkers. Cancers 2021, 13 , 3230. https://doi.org/10.3390/ cancers 13133230

Academic Editor: David Wong

Received: 31 May 2021

Accepted: 23 June 2021

Published: 28 June 2021

Publisher's Note: MDPI stays neutral with regard to jurisdictional claims in published maps and institutional affiliations.

Copyright: (c) 2021 by the authors. Licensee MDPI, Basel, Switzerland. This article is an open access article distributed under the terms and conditions of the Creative Commons Attribution (CC BY) license (https:// creativecommons.org/licenses/by/ $4.0 /)$.
Simple Summary: Cancer cells reprogram their metabolism to meet the bioenergetic, biosynthetic and redox demands required to maintain tumor formation, growth and dissemination. Additionally, rewired metabolism in the tumor microenvironment contributes to immune evasion by depleting key nutrients required for mounting a proper immune response, but also by producing immunosuppressive metabolites. Altered cancer metabolism can be exploited therapeutically by targeting cancer cell activities required for biomass and energy production, but also by alleviating the immunosuppressive properties of the tumor microenvironment. Using imaging techniques (i.e., magnetic resonance spectroscopy (MRS), positron emission tomography (PET), magnetic resonance imaging (MRI)) or the liquid chromatography coupled to mass spectrometry (LC-MS)-based analysis of biofluids, altered metabolites produced by dysregulated cancer metabolism can be used as noninvasive biomarkers for diagnosis and therapy.

Abstract: Metabolic reprogramming is a hallmark of cancer that enables cancer cells to grow, proliferate and survive. This metabolic rewiring is intrinsically regulated by mutations in oncogenes and tumor suppressors, but also extrinsically by tumor microenvironment factors (nutrient and oxygen availability, cell-to-cell interactions, cytokines, hormones, etc.). Intriguingly, only a few cancers are driven by mutations in metabolic genes, which lead metabolites with oncogenic properties (i.e., oncometabolites) to accumulate. In the last decade, there has been rekindled interest in understanding how dysregulated metabolism and its crosstalk with various cell types in the tumor microenvironment not only sustains biosynthesis and energy production for cancer cells, but also contributes to immune escape. An assessment of dysregulated intratumor metabolism has long since been exploited for cancer diagnosis, monitoring and therapy, as exemplified by 18F-2-deoxyglucose positron emission tomography imaging. However, the efficient delivery of precision medicine demands less invasive, cheaper and faster technologies to precisely predict and monitor therapy response. The metabolomic analysis of tumor and/or microenvironment-derived metabolites in readily accessible biological samples is likely to play an important role in this sense. Here, we review altered cancer metabolism and its crosstalk with the tumor microenvironment to focus on energy and biomass sources, oncometabolites and the production of immunosuppressive metabolites. We provide an overview of current pharmacological approaches targeting such dysregulated metabolic landscapes and noninvasive approaches to characterize cancer metabolism for diagnosis, therapy and efficacy assessment.

Keywords: biomarkers; cancer metabolism; oncometabolites; metabolomics; imaging; LC-MS; cancer therapy; metabolic inhibitors; MRS; MRI 


\section{Introduction}

Despite the first observations of metabolic alterations in tumors, such as cancer cell dependency on aerobic glycolysis, being first documented one century ago [1], cancer metabolism re-emerged as a hot topic in the field of oncology in the last decade. Presently, tumor-altered metabolism is unquestionably considered a hallmark of cancer [2]. Cancer cells reprogram their metabolism to meet the bioenergetic, biosynthetic and redox demands required to maintain tumor formation, growth and dissemination [3-5]. Rather than conducted by mutations in metabolic genes, this metabolic reprogramming is usually intrinsically modulated by the action of oncogenes and suppressor genes (e.g., KRAS, EGFR, p53, MYC, PTEN or LKB1). However, mutations in the metabolic enzymes isocitrate dehydrogenase $1 / 2(I D H 1 / 2)$, fumarate hydratase $(F H)$ and succinate dehydrogenase $(S D H)$ also result in oncogenic transformation through mechanisms exerted by the accumulation of oncometabolites D-2hydroxyglutarate (D-2HG), fumarate and succinate, respectively $[3,5]$.

Established cancers are surrounded by a large heterogeneous collection of infiltrating and resident host cells (fibroblasts, immune cells, adipocytes, endothelial cells), secreted factors and extracellular matrix that are collectively known as the tumor microenvironment (TME) [6,7]. In the TME, these various cells types establish crosstalk mediated not only by direct cell-cell interactions or paracrine signaling (i.e., cytokines, chemokines, growth factors, inflammatory mediators, etc.), but also by metabolic factors (limited nutrient availability, nutrient competition, production of immunomodulatory/signaling metabolites, etc.) $[4,5,8]$. From a metabolic perspective, such interactions may enhance the activity of a given metabolic enzyme or up-regulate transcription factors that, in turn, increase the expression of metabolic regulators [5] and alters metabolic and/or signaling pathways. The complex interplays in TME results in a dynamic scenario in which metabolic and nonmetabolic conditions vary over time. From a biomass and energy production perspective, cancer cells have demonstrated possessing a high plasticity in adapting their metabolism to these changing conditions that enables them to overcome nutrient and oxygen limitations. Some of the enhanced tumor metabolic pathways include up-regulated glycolysis, glutaminolysis, fatty acid (FA) catabolism and OXPHOS, depending on oncogenic mutations, tissue of origin and tissue location $[9,10]$. In addition to the more efficient use of canonical nutrients and metabolic pathways, cancer cells can exploit diverse carbon and nitrogen sources for biomass and energy production (e.g., branched-chain amino acids (BCAAs), acetate, ammonia, etc.), and even modulate the metabolism of cancer-supporting cells to hijack the key nutrients they need $[3-5,8,11]$. In addition to this, upon the inhibition of a particular enzyme/route, cancer cells can up-regulate compensatory pathways to overcome the targeting of a particular metabolic vulnerability [12]. So, although there are several inhibitors of key cancer enzymes with astonishing results in vitro, and even in preclinical in vivo models, their benefits are more limited when translated into clinical trials either by lack of efficacy or toxicity. Some explanations for such lack of efficacy include similarities between cancer and immune cells metabolism [13,14], the supporting metabolic activities of cancer-associated cells [15-17], and our yet far-from-being-complete knowledge about the actual metabolic and non-metabolic conditionings of the TME. Apart from all this, cancer cells can directly or indirectly, through their influence on cancer-surrounding cells, produce immunosuppressive metabolites that restrict the access or function of antitumor immune cells in the TME. These combined metabolic interactions may enable cancer cells to cover their metabolic needs and to evade immune surveillance and destruction $[18,19]$. Targeting altered cancer metabolism as a therapeutic avenue is not a new idea. In fact, the use of antifolates to treat leukemia dates back to the 1940s [20]. However, our increasing knowledge about the specificity of cancer-related metabolic alterations and findings showing that not only cancer cells metabolic reprogramming, but also their metabolic interplay with host cells plays an active role in supporting cancer, have widened the range of new therapeutic opportunities.

The assessment of dysregulated intratumor metabolism has long since been exploited for cancer diagnosis, monitoring and therapy. Of the different in vivo imaging techniques 
that rely on metabolic determinations, positron emission tomography (PET), magnetic resonance spectroscopy (MRS) and magnetic resonance imaging (MRI) stand out as the most widely used. These techniques enable the characterization of discrete metabolic features and constraints of a tumor (i.e., preferred use of a particular nutrient or production of a given immunosuppressive metabolite) and, thus, these techniques can also tailor the therapeutic approach that will best work to target a specific metabolic landscape defined by tumor idiosyncrasy [4,21]. Interestingly, tumor- and TME-derived metabolites can also be found in different biospecimens such as blood, which presents a new biomarker discovery strategy. The metabolomic analysis, understood as the holistic determination of all small molecules present in a biological sample, is a powerful technology to both identify new biomarkers and cancer drivers of tumorigenesis and to provide new mechanistic insights into cancer metabolism and metabolic crosstalk between cancer cells and host cells in the TME $[11,22,23]$. By understanding the metabolic characteristics and constraints of tumors in a personalized manner, metabolic-based cancer treatments can be delivered more efficiently and safely.

Here we review how tumor metabolism and its crosstalk with the TME play an important role in supporting cancer initiation and growth, and in modulating the immune response, which collectively pose new therapeutic opportunities. We also provide an overview of current pharmacological approaches targeting such dysregulated metabolic landscapes. Finally, we describe up-to-date metabolite-based technologies that are routinely used in oncology (PET, MRS, MRI, etc.) along with other emerging tools, such as metabolomics, to focus on their capabilities for identifying metabolic targets, discovering biomarkers and monitoring metabolic therapeutic interventions.

\section{Metabolites Used as Biomass and Energy Sources by Cancer Cells}

Oncogenic transformation integrates internal and external signals to orchestrate a metabolic program that supports cell survival, proliferation and dissemination. On the one hand, cancer cells can more efficiently uptake or metabolize common nutrients such as glucose, glutamine or FA. On the other hand, they can adapt to the nutrient and oxygen limitations of the TME using alternative carbon and nitrogen sources [3-5,8,11] (Figure 1). The metabolic alterations and vulnerabilities of cancer cells depend on oncogenic mutation, tissue of origin and tissue location $[9,10]$, but also vary over time and in response to therapy [4].

Glucose is the preferred nutrient of cancer cells by definition since the early observations of Otto Warburg in the 1920s [1]. Several attempts have been made to target glucose metabolism in cancer. 2-deoxy-D-glucose (2-DG) is a non-metabolizable glucose analog that can be phosphorylated by hexokinase in the first glycolysis step, but it cannot be further metabolized. The effects of 2-DG go beyond the inhibition of glucose-dependent reactions, and it also interferes with $\mathrm{N}$-linked glycosylation [24]. Despite its efficacy in vitro and in preclinical models, its use as a single agent in a clinical setting does not provide acceptable results, such as lack of efficacy, toxicity and off-target effects [24-26]. It has been proposed that through ATP depletion, 2-DG can be used as sensitizing agent in combination with other drugs or with radiotherapy, although contradictory results have been obtained [24-26]. An alternative strategy to target glucose metabolism is to inhibit glucose transporters, particularly GLUT1, which is overexpressed in many cancers. GLUT1-specific inhibitor BAY-876 [27] and more promiscuous inhibitors STF-31 [28], WZB117 [29], and Glutor [30], have demonstrated efficacy inhibiting glucose uptake in not only in vitro models, but also in vivo across a wide range of high glycolytic tumors, although none is being tested in clinical trials [28,29,31]. Alternatively, particular glucose metabolism enzymes/transporters can be targeted for therapeutic purposes. The most predominant targets are those in glycolysis, including monocarboxylate transporters (MCTs) and lactate dehydrogenase (LDH). Glucose catabolism via glycolysis produces two pyruvate molecules, with the associated production of two ATP and two NADH molecules. NAD ${ }^{+}$regeneration is essential to sustain glycolysis, and also for the biosynthesis of the amino acids and 
nucleotides required for proliferation [32-34]. $\mathrm{NAD}^{+}$regeneration can be achieved by respiration in mitochondria, but also by the conversion of pyruvate into lactate catalyzed by LDH. When the $\mathrm{NAD}^{+}$demand to support oxidation reactions exceeds the ATP turnover rate in cells, $\mathrm{NAD}^{+}$regeneration by mitochondrial respiration is limited, which promotes fermentation despite available oxygen [35]. MCTs mediate the transport of both pyruvate and lactate across membranes, and allow not only the release of lactate when produced in excess, but also its import to be used as fuel for TCA oxidation. Both MCT (mainly MCT1) and LDH inhibitors increase intracellular NADH and effectively inhibit glycolysis. MCT1 inhibitors SR13800 (AR-C122982) [36], AR-C155858 (SR138001) [37], BAY-8002 [38] and AZD3965 [39] effectively increase intracellular tumor lactate concentrations which in turn inhibit proliferation in vitro and in vivo [38-41]. AZD3965 is an orally bioavailable MCT1 inhibitor that is currently in a phase I clinical trial. Increased MCT4 expression is a mechanism of resistance to MCT1 inhibition and a dual MCT1/4 inhibitor, syrosingopine, has been described [42]. LDH inhibitors FX11 [43], NCI-006 and NCI-737 [44] also have the proven ability to inhibit cell proliferation and control tumor growth in vivo [43,45,46]. Although both LDH and MCT inhibitors achieve tumor control, increased mitochondrial catabolism compensates for deficient glycolysis and, thus, only the glycolysis and respiration (OXPHOS) inhibition combination achieves efficient tumor regression [42,45,47]. Like MCT and LDH inhibitors, OXPHOS inhibitors increase intracellular NADH. Increased mitochondrial NADH shuts down TCA and induces both an energy and a biosynthesis crisis [48]. The drugs targeting mitochondrial complex I, such as IACS-010759 [49], or antidiabetic drugs metformin and phenformin [50,51], effectively inhibit growth in those tumors that rely on OXPHOS for energy production or depend on TCA for aspartate biosynthesis [49,52-54].

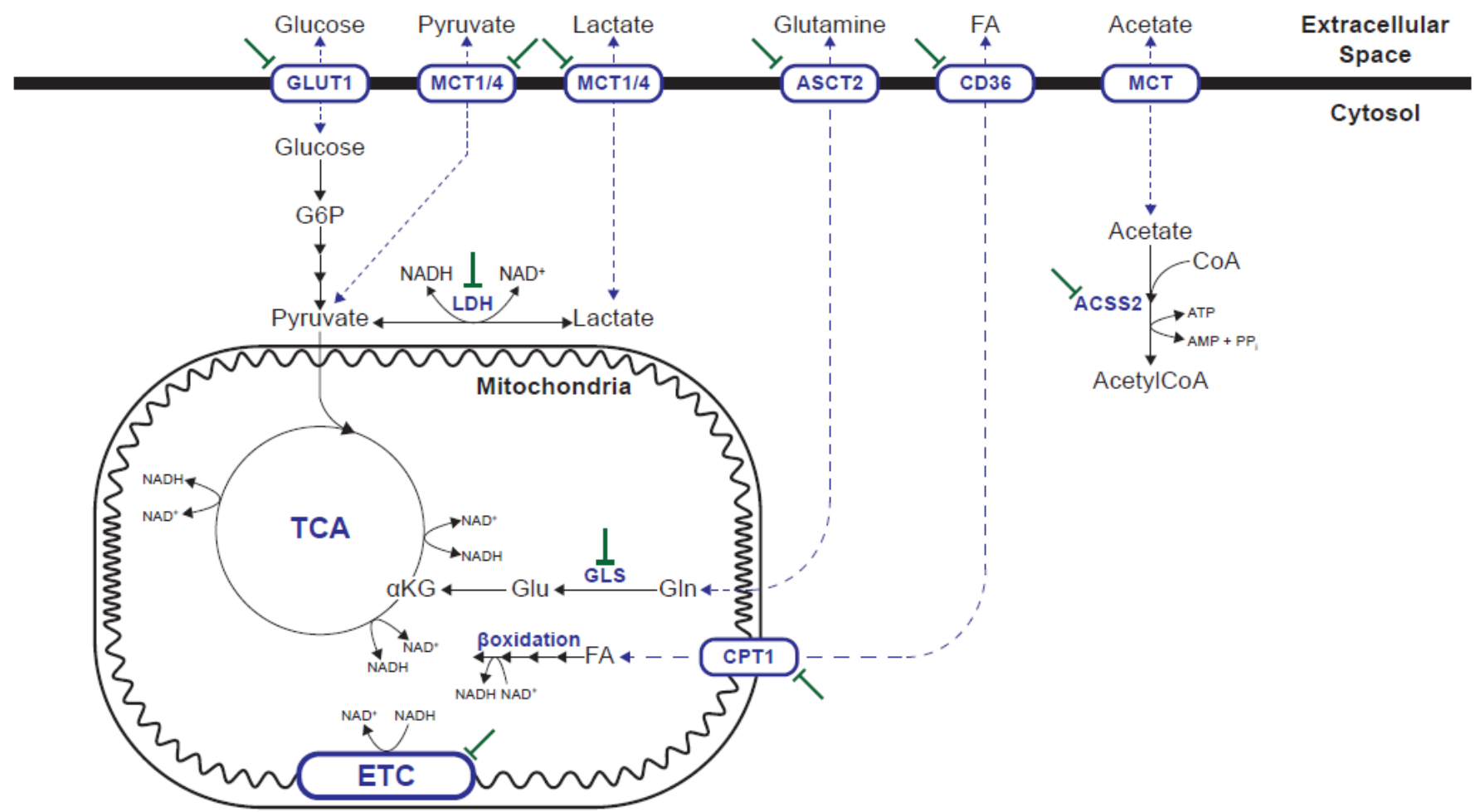

Figure 1. Metabolic pathways supporting biosynthesis and energy production in cancer cells that can be pharmacologically targeted. GLUT1: glucose transporter 1; MCT: monocarboxylate transporter; ASCT2: alanine, serine, cysteine transporter 2, SLC1A5; LDH: lactate dehydrogenase; ACSS2: acetyl-CoA synthetase 2; GLS: glutaminase. CPT1: carnitine palmitoyltransferase 1; ETC: electron transport chain.

Glutamine is the most abundant circulating amino acid in blood and plays a key role in energy production, redox homeostasis, macromolecular synthesis and signaling 
in cancer cells $[55,56]$. Thus, glutamine metabolism inhibition has been approached as a therapeutic target in cancer for several decades. 6-diazo-5-oxo-L-norleucine (DON) is a broad glutamine antagonist with potent in vitro efficacy. However, its unacceptable toxicity hampers its clinical application [57]. To minimize DON side effects, a series of prodrugs of DON have been designed to circulate and remain intact until they arrive at the TME for their in situ enzymatic cleavage to release the drug [57,58]. Of them, [ethyl 2-(2-amino4-methylpentanamido)-DON] (also known as JHU083 and DRP-083) has demonstrated glutamine metabolism inhibition in a wide array of tumors in preclinical in vivo models [59]. An alternative strategy for the complete glutamine metabolism blockade is to inhibit glutaminase (GLS), which is a key enzyme in anaplerotic glutamine use $[55,56]$. The efficacy of the small-molecule inhibitor of GLS, including compound 968, BPTES and its derivative CB-839 in vitro and in preclinical in vivo models, offers a new possibility of targeting glutamine metabolism in cancer [60-64]. Glutamine catabolism inhibition not only suppresses the oxidative and glycolytic metabolism of cancer cells, but also restores $\mathrm{CD}^{+} \mathrm{T}$-cell function in vivo [59]. The combination of glutamine catabolism with adoptive T-cell transfer or anti-PD1 treatment is superior than any the treatments alone $[59,65]$. CB839 (under the name of Telaglenastat) is currently under study in several clinical trials. A completely different strategy to target glutamine metabolism is to block its cellular import. Of the several transporters that can mediate glutamine uptake across the cellular membrane, ASCT2 (encoded by gene SLC1A5) seems to play a key role in various cancers [66-68]. Blockade of ASCT2 with small-molecule inhibitor V-9302 results in attenuated cancer cell growth and proliferation, increased cell death and oxidative stress, which collectively contribute to antitumor responses in vitro and in vivo [69].

FAs are key nutrients that are not only used as fuel for energy production, but also for biosynthesis of complex lipids. In addition to their metabolic role, FAs play many roles in both cancer cells and the TME [70]. Uptake and use of external FAs are particularly relevant for certain cancer types, including ovarian [16,71], colorectal [72], breast [73,74] and mutant KRAS lung cancer [75], while FA translocase CD36 has been demonstrated to play a key role in metastasis [71,76]. CD36 inhibition using either anti-CD36 monoclonal antibodies (mAbs) or oleic acid analog sulfo-n-succinimidyl oleate (SSO), which irreversibly binds CD36, have proven efficacy in preventing tumor growth and metastasis in preclinical models [71,76-78]. However, CD36 is relevant not only to provide FA in cancer cells, but also sustains tumor-supportive MDSCs, Tregs and M2 macrophages [79-82]. Targeting Tregs with a mAb against CD36 elicits additive antitumor responses with anti-PD1 immunotherapy [79]. FA oxidation (FAO) can be halted by the inhibition of carnitine palmitoyltransferase I (CPT1), which enables FAs to enter mitochondria through their binding to carnitine, which is the rate-limiting step in mitochondrial FAO. Etomoxir is an irreversible CPT1 inhibitor whose value in preclinical models for preventing tumor growth and metastasis has been demonstrated $[73,83,84]$. However, recent studies have shown that the actual antitumor effects observed at the high doses required to inhibit tumor growth might be due to the impairment of OXPHOS rather than actual CPT1 inhibition [85-87]. Given the role of enhanced FA uptake by cancer and cancer-associated cells in promoting tumorigenesis through immune suppression [88,89], targeting lipid metabolism holds an very high potential for the development of new treatments to synergize with current immunotherapies [70].

One key ability of cancer cells is their adaptation to the dynamic environmental conditions of the TME, including the use of alternative carbon and nitrogen sources. The enzyme acetyl-CoA synthetase 2 (ACSS2) is expressed in a wide range of cancer cells and allows the use of acetate to generate acetyl-CoA that is used, in turn, for FA synthesis, protein acetylation and energy production [90-92]. ACSS2 expression is up-regulated under metabolically stressed conditions (low oxygen and low nutrient/lipid availability) and ACSS2 silencing has been shown to reduce the growth of tumor xenografts [92]. Small-molecule inhibitors VY-3-135 and VY-3-249 impair tumor growth in vivo in a breast cancer model that shows high ACSS2 expression [93] and in a model of obesity-induced 
myeloma [94], respectively. The development of small-molecule inhibitors of ACSS2 is an active research field [95]. In proliferating cells, glucose and glutamine are not the sources of the majority of cell mass, and non-glutamine amino acids provide abundant carbon and nitrogen for biomass and also for energy production [96]. Some cancer types show increased dependence on BCAAs for protein synthesis, carbon and nitrogen sources and for energy production. Catabolism of BCAAs is mediated by BCAA aminotransferase $1 / 2$ (BCAT1/2). The knockdown or pharmacological inhibition of BCAT1/2 results in decreased proliferation and tumor growth of BCAT1/2-dependent cancer cells [97-100]. Thus, BCAT1/2 inhibition is a promising therapeutic target in a subset of cancers. Ammonia is a ubiquitous by-product of cellular metabolism. It has been recently demonstrated that ammonia in mice accumulates in the TME and is used by breast cancer cells directly to generate amino acids through GDH activity. Thus, the recycling of circulating ammonia can support cancer biomass and can be pharmacologically exploited to treat cancer [101].

\section{Oncometabolites}

Oncometabolites can be defined as metabolites whose abnormal accumulation causes both metabolic and non-metabolic dysregulation and potential transformation to malignancy [102]. To date, three oncometabolites have been identified: fumarate, succinate and D-2HG. The accumulation of fumarate and succinate results from loss-of-function mutations in mitochondrial Krebs cycle enzymes FH and SDH, respectively. D-2HG accumulation is the result of a gain-of-function in either IDH1 or 2, respectively localized in the cytoplasm and mitochondria. Wild-type (wt) IDH1/2 homodimers catalyze the $\mathrm{NADP}^{+}$-dependent and reversible conversion of isocitrate into $\alpha$-ketoglutarate $(\alpha-\mathrm{KG})$, whereas the heterodimers between mutant and wtIDH1/2 display neomorphic activity that allows the reduction of $\alpha-K G$ directly to D-2HG in the presence of NADPH [102-104] (Figure 2).

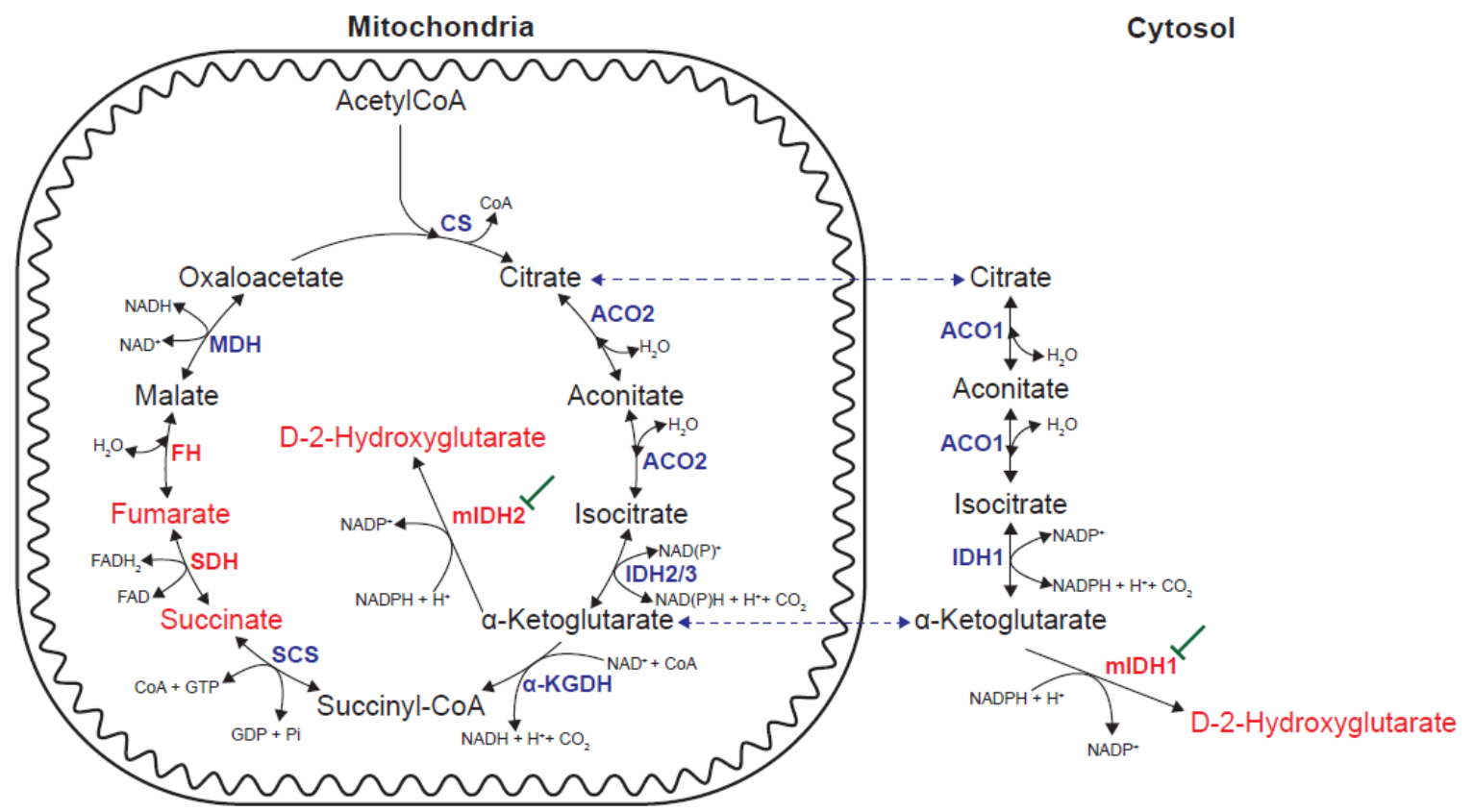

Figure 2. Alterations in enzymatic activities leading to the accumulation of oncometabolites. Gain-of-function mutations in IDH1/2 (mIDH1/2) lead to the production of D-2-hydroxyglutarate. mIDH1/2 can be pharmacologically inhibited. Loss-of-function mutations in SDH and FH lead to the accumulation of succinate and fumarate, respectively. CS: citrate synthase; ACO: aconitase; IDH: isocitrate dehydrogenase; $\alpha-\mathrm{KGDH}$ : $\alpha$-ketoglutarate dehydrogenase; SCS: succinyl-CoA synthetase; $\mathrm{SDH}$ : succinate dehydrogenase; FH: fumarate hydratase; $\mathrm{MDH}$ : malate dehydrogenase.

Succinate, fumarate and D-2HG have individual and shared mechanisms of action. A common oncogenic mechanism linking D-2HG, succinate and fumarate is the inhibition 
of $\alpha$-KG-dependent dioxygenases, which results in epigenetic alterations that impede normal differentiation programs and, thus, induce transformation [102,105]. Succinate and fumarate also inhibit $\alpha$-KG-dependent prolyl-hydroxylase (PHD), which creates a pseudohypoxia state through hypoxia-inducible factor $1 \alpha$ (HIF1 $\alpha$ ) stabilization. In addition to this, fumarate can modify proteins by succination, a post-translation modification of cysteine residues by forming S-(2-succino)-cysteine. Fumarate accumulation upon FH lossof-function mutations induces the succination of several proteins, including aconitase and Kelch-like ECH-associated protein 1 (KEAP1). KEAP1 succination disrupts its interaction with transcription factor nuclear factor erythroid 2-related factor 2 (NRF2) which, thus, prevents its proteosomal degradation. Increased NFR2 activity promotes a reductive environment that supports survival and proliferation [102,105].

Inhibition of mIDH1 or mIDH2 with small-molecule inhibitors specific of mutant isoforms lowers D-2HG levels and induces differentiation in vitro and in vivo to result in prolonged survival in preclinical models [106-108]. mIDH1 inhibitor Ivosidenib (AG120) $[109,110]$ and miDH2 inhibitor Enasidenib (AG-221/CC-90007) [111] have been approved by the FDA to treat acute myeloid leukemia (AML) and there are several candidates in clinical trials, including LY3410738, Olutasidenib, BAY 1436032 or IDH305 [112]. One ongoing development is to improve brain penetrance, which is key to extend the application of mIDH1/2 inhibitors to gliomas, and a first-in-class brain-penetrant dual inhibitor of mIDH1 and mIDH2, Vorasidenib (AG-881), is currently being evaluated in clinical trials to treat glioma [113]. The commonest IDH1 mutation in gliomas affects codon 132 and encodes IDH1(R132H). From an immunological perspective, IDH1(R132H) represents a potential immunotherapy target because it is a tumor-specific potential neoantigen that is indeed presented in major histocompatibility complex class II (MHCII) and can, thus, evoke a robust immune response in $\mathrm{CD}^{+} \mathrm{T}$ cells [114]. The first-in-humans phase I trial of an IDH1(R132H)-specific peptide vaccine has been recently reported [115].

\section{Immunosuppressive Metabolites and Metabolic Activities}

Cancer cells adapt their metabolism to grow and survive in a hostile environment. This rewired metabolism promotes other effects that sustain tumor progression through immune escape. The preferential use of nutrients by cancer cells or other cell types in the TME (cancer-associated fibroblasts (CAFs), myeloid-derived suppressor cells (MDSCs), tumor-associated macrophages (TAMs), etc.) may restrict their uptake by immune cells and, thus, compromise their functionality. Additionally, in the TME, immunosuppressing metabolites can be released by cancer cells and other resident cells to promote cancer cells immune escape.

It has been shown in highly glycolytic tumors that glucose depletion in tumor interstitial fluid (TIF) leads to T-cell impairment and, hence, inadequate immune tumor suppression [89,116-118]. However, glucose depletion might not be the only, or even the commonest, nutrient deprivation that immune cells encounter in the TME. It has been recently reported that tumor-infiltrating $\mathrm{T}$ lymphocytes (TILs) display a similar per cell glucose uptake as cancer cells [119]. Indeed, the cells displaying the highest per cell glucose consumption are TAMs and MDSCs, while cancer cells display the highest per cell consumption rate of FAs and glutamine [119]. Thus, while glucose restriction in the TME might occur in some circumstances, deprivation may affect other metabolites. Indeed, in situations in which the reported glucose levels in TIF come close to those encountered in plasma, a sharp drop in other key nutrients, including arginine, tryptophan and cystine, has been found [120]. Although cancer cells themselves modify the metabolic composition of TIF, tumor-supporting cells in the TME play a key role in this sense. For instance, MDSCs and TAMs are responsible for the depletion of amino acids arginine, tryptophan and cystine from TIF $[18,121]$. The involved mechanisms include arginine degradation via arginase 1 (ARG1) [122], by sequestering cystine and limiting cysteine availability [123] and by catabolizing tryptophan via indoleamine 2,3 dioxygenase 1 (IDO1) [124,125]. Some cancer cells can also degrade tryptophan through an alternative pathway by tryptophan- 
2,3-dioxygenase 2 (TDO2) activity [126,127]. In addition to the depletion of those nutrients required for sustaining proper immune surveillance of tumors, tumor and tumor-associated cells also produce metabolites that directly inhibit the immune cell function, including kynurenine, D-2HG, adenosine, lactate, 1-methylnicotinamide (1-MNA) and methylglyoxal (Figure 3). The concomitant use of immunotherapy and complementary therapies to diminish the immunosuppressive metabolic properties of the TME is promising for improving the benefit of immune-based therapies.

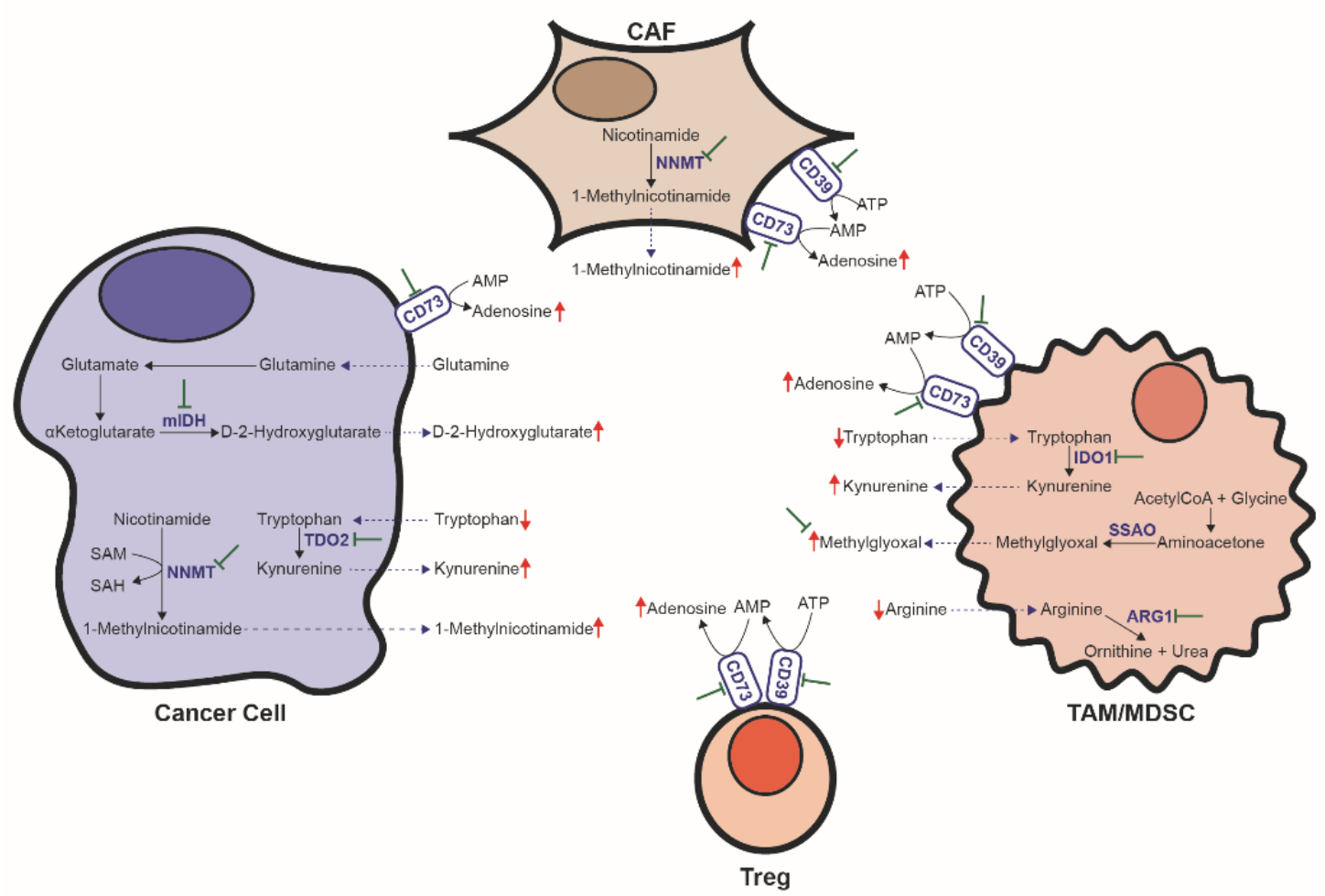

Figure 3. Metabolic activities contributing to immune suppression in the tumor microenvironment. Metabolic activities depleting key nutrients include arginine degradation by ARG1 and tryptophan degradation by IDO1/TDO2. Metabolic activities producing immunosuppressive metabolites include 1-MNA production by NNMT, kynurenine synthesis from tryptophan by IDO1/TDO2, D-2HG synthesis by mIDH1/2, adenosine production from ATP/AMP by the combined activities of CD39 and CD73 and production of methylglyoxal by SSAO. CAF: cancer-associated fibroblast; TAM: tumor-associated macrophage; MDSC: myeloid-derived suppressor cell. mIDH: mutant isocitrate dehydrogenase. TDO2: tryptophan-2,3dioxygenase 2; NNMT: nicotinamide N-methyltransferase; IDO1: indoleamine 2,3 dioxygenase 1; ARG1: arginase 1; SAM: S-adenosylmethionine; SAH: S-adenosylhomocysteine; SSAO: semicarbazide-sensitive amine oxidase.

L-Arginine is required to sustain T-cell growth and proliferation [128]. Myeloid cells in the TME contribute to immune suppression by depleting arginine via increased ARG1 activity [122]. ARG1 inhibition with small-molecule inhibitor CB-1158 blocks the myeloid cell-mediated suppression of T-cell proliferation in vitro and reduces tumor growth in many mouse models of cancer as a single agent and also in combination with checkpoint blockade, adoptive T-cell therapy, adoptive natural killer (NK) cell therapy and chemotherapy agent gemcitabine [129].

Both tumor cells and TAMs/MDSCs can decrease tryptophan availability in the TIF to levels that compromise the immune function [124-127]. Additionally, tryptophan catabolism through IDO1/TDO2 produces kynurenine, an endogenous ligand of human aryl hydrocarbon receptor (AHR), which limits effector T-cell proliferation [127], promotes the differentiation of $\mathrm{CD} 4^{+} \mathrm{T}$ cells into immunosuppressive regulatory $\mathrm{T}$ cells (Tregs) [130,131], and negatively regulates dendritic cell immunogenicity [132]. Although the inhibition of IDO1 and TDO2 alone does not lead to satisfactory results, it enhances tu- 
mor regression and control when combined with immunotherapy [126,133-136]. Currently, several IDO inhibitors (Indoximod, Epacadostat, Navoximod, Linrodostat Mesilate, PF06840003, KHK2455, etc.) form part of clinical trials to evaluate their efficacy in enhancing immunotherapy in various cancer types [137]. Although it has been recently announced that Epacadostat plus pembrolizumab (anti-PD-1) does not improve progression-free survival or overall survival compared to placebo plus pembrolizumab in patients with unresectable or metastatic melanoma [138], the reasons for failure are unclear. Ongoing clinical trials report encouraging preliminary results, and the usefulness of IDO1 inhibitors as a strategy to enhance anti-PD-1 therapy activity in cancer is still under study. A different approach to target the tryptophan/kynurenine inhibitory axis is to inhibit signaling through AHR. Administering an AHR inhibitor in combination with immunotherapy (anti-PDL1) significantly prolongs the survival of mice bearing $\mathrm{mIDH} 1$ tumors, but not in those bearing wtIDH1 tumors, compared to immunotherapy alone. Although the AHR inhibitor can directly affect the signaling of kynurenine in T cells, it seems that the main effect in this case is exerted on macrophages [139].

In addition to its capacity to induce malignant transformation, oncometabolite D-2HG also has immunosuppressive properties. Compared to gliomas with wtIDH1/2, IDHmutated gliomas show small numbers of tumor-infiltrating $\mathrm{CD}^{+}$and $\mathrm{CD}^{+} \mathrm{T}$ cells [140] and a low expression of cytotoxic T-lymphocyte-associated genes and IFN- $\gamma$-inducible chemokines, including CXCL10 [141]. D-2HG can be taken up by T cells, which interferes with the calcium-dependent transcriptional activity of the nuclear factor of activated $\mathrm{T}$ cells (NFAT) by inhibiting ATP-dependent TCR signaling and polyamine biosynthesis in T cells. Thus, D-2HG has paracrine effects on $\mathrm{T}$ cells that suppresses T-cell activation, proliferation and cytolytic activity, and compromises antitumor immunity [142]. It has been recently reported that tryptophan catabolism is a key modulator of immune suppression in mutant IDH1 (mIDH1) gliomas. D-2HG accumulation in the TME blocks the differentiation of infiltrating macrophages and induces a re-orchestration of tryptophan metabolism, including increased AHR expression, TDO2 activity and kynurenine production [139]. Due to the immune suppression properties of D-2HG, the antitumor properties of immunotherapies based on a mIDH1-specific vaccine or checkpoint inhibition are improved by inhibition of mIDH1 in tumors bearing that particular mutation [141,142].

Increased adenosine levels have been reported in the TME [143,144]. Adenosine and associated nucleotides (i.e., ATP, ADP, AMP) can be passively released as a result of cancer tissue hypoxia, ischemia and necrosis, but also actively due to altered metabolism in cancer and cancer-associated cells [145]. Adenine-containing nucleotides can be hydrolyzed in the TME by the sequential activities of ectoenzymes CD39 and CD73, which convert ATP (or ADP) into AMP and AMP into adenosine, respectively [145]. They are present in both cancer and immunosuppressive cells in the TME [146-150]. Adenosine signaling through the interaction with adenosine receptor A2A impairs NK [151] and effector T cells [152-154], and promotes the generation of immunosuppressive Tregs [155]. In preclinical models, the targeted inhibition of the immunosuppressive adenosine pathway by targeting CD73, CD39, or adenosine receptors $\mathrm{A} 2 \mathrm{~A}$ or $\mathrm{A} 2 \mathrm{~B}$ with either small-molecule inhibitors or mAbs can restore antitumor immunity and enhance the efficacy of cancer immunotherapies [156-161]. To date, several mAbs against CD73 (including oleclumab (MEDI9447), BMS-986179, CPI006 and NZV930), mAbs against CD39 (TTX-30, SRF617 and IPH5201), small-molecule inhibitors against CD73 (AB680, CB-708 and LY3475070) and small-molecule A2A receptor antagonist (AZD4635, taminadenant (NIR178; PBF-509), ciforadenant (CPI-444), EOS100850 and preladenant (MK-3814A)), as well as one dual A2A and A2B antagonist (AB928), have entered into clinical trials. Promising results are reported for those that are already being tested, usually in combination with immunotherapy [162].

Lactate is the end product of glycolysis. Consistent with the Warburg effect, lactate is the most consistently up-regulated metabolite across diverse tumors [11]. In vitro, high concentrations of lactate/lactic acid can drive T cells toward an immunosuppressive Treg phenotype [163] and limit the proliferation and antitumor function of both innate and 
adaptive lymphocytes [163-165]. In vivo, high $L D H A$ expression is associated with poor immune surveillance in the TME $[165,166]$. However, while decreased glucose levels in the TIF have been reported in highly glycolytic tumors, corresponding lactate data are in most cases not available or do not show an increase up to levels that impede proper immune response [11]. Conversely, in highly glycolytic tumors or in tumors with high LDHA expression, lactate may accumulate inside tumor cells and the immunosuppressive effects can be due to acidic $\mathrm{pH}$ and insufficient glucose levels (among other required nutrients) in the TIF [11]. Nevertheless, preventing lactate production (i.e., via glycolysis inhibition with MCT or LDH inhibitors) is a valid strategy to avoid tumor growth and restore immune function as previously discussed. Moreover, transient LDH inhibition enhances the generation of memory $\mathrm{CD} 8^{+} \mathrm{T}$ cells capable of triggering robust antitumor responses after adoptive transfer [167].

Nicotinamide N-methyltransferase (NNMT), which catalyzes the transfer of a methyl group from S-adenosylmethionine (SAM) to nicotinamide, is overexpressed in a variety of human cancers (in both cancer and cancer-supporting cells), where it contributes to tumorigenesis through epigenetic remodeling by creating a metabolic methylation sink $[168,169]$. The product of the reaction, 1-MNA, can be taken up by TILs. Functionally, 1-MNA induces T cells to secrete tumor-promoting cytokine tumor necrosis factor alpha (TNF- $\alpha$ ), reduces IFN- $\gamma$ secretion in $\mathrm{CD}^{+} \mathrm{T}$ cells and has been shown to induce a significant reduction in chimeric antigen receptor (CAR)-T-cell killing activity [170]. The development of potent specific NNMT inhibitors with favorable pharmacokinetic and pharmacodynamics properties is an active, yet still emerging research field that may induce a favorable response in combination with immunotherapy through tumor growth restriction and a decrease in immunosuppressive metabolite 1-MNA [171-174].

We have already discussed the key role of MDSCs in the metabolic and non-metabolic immune suppression in the TME. It has been recently shown that production of the glycolysis by-product methylglyoxal by the enzyme semicarbazide-sensitive amine oxidase (SSAO) can be an additional metabolic mechanism by which MDSCs inhibit T cells. Methylglyoxal is a reactive compound that attacks amino/guanidine-groups $(\mathrm{HN}=\mathrm{C}-(\mathrm{NH} 2)-\mathrm{NH})$ and, thus, preferentially targets amino acids l-lysine and l-arginine, as well as their residues in proteins, to form advanced glycation end products (AGPs) that can render amino acids and proteins non-functional. Upon the transfer to T cells, methylglyoxal depletes arginine and causes a concomitant increase in the methylglyoxal-derived glycation products of l-arginine. As a result, methylglyoxal completely halts T-cell activation, proliferation and cytokine production [175]. In a murine cancer model, neutralization of methylglyoxal with dimethylbiguanide released MDSC-mediated T-cell suppression and, together with checkpoint inhibition, improved the efficacy of a vaccine-based cancer immunotherapy [175].

\section{Noninvasive Measurement of Metabolites as Biomarkers in Cancer}

We have shown how altered TME metabolism can be targeted for therapeutic purposes. Additionally, such cancer metabolism can be also informative of tumor presence or tumor status. Therefore, the noninvasive assessment of these tumor-derived metabolites could appear as a strategy to discover new biomarkers (diagnosis, prognosis, monitoring, stratification, etc.), which would be very interesting from a clinical perspective. Most of the above-mentioned metabolic alterations have been discovered by either using in vitro models or analyzing tumor biopsies from patients and animal models. However, they can be assessed in patients by two complementary approaches. The in vivo metabolism assessment in tissues can be performed by MRS, PET-based and MRI techniques [21]. Additionally, the altered metabolic properties of tumors may result in changes of the circulating and/or excreted metabolites present in readily accessible biological samples. There are different techniques that allow the sensitive and accurate determination of small molecules (i.e., metabolites) in different biological fluids, including enzymatic assays (coupled to various detection methods, such as absorbance, fluorescence or electric current/potential), liquid chromatography (LC) or gas chromatography (GC) separation usually coupled 
to mass spectrometry (MS) detection and nuclear magnetic resonance (NMR). However, to date, LC-MS stands out as the most widely used technique for both exploratory and validated targeted analyses [22].

\subsection{MRS/MRI/PET}

PET, MRS and MRI are complementary techniques that allow the study in vivo of intact tissues. MRS uses high-powered magnetic fields to quantify chemical compounds in tissue. Endogenous isotopes detectable by magnetic resonance include ${ }^{1} \mathrm{H}$ (protons) and ${ }^{31} \mathrm{P}$, whereas ${ }^{13} \mathrm{C},{ }^{19} \mathrm{~F}$, and ${ }^{17} \mathrm{O}$ containing tracers can also be used. PET measures the distribution of positron-emitting radioactive isotopes from an injected tracer. These radioisotopes include ${ }^{11} \mathrm{C},{ }^{13} \mathrm{~N},{ }^{15} \mathrm{O}$, and ${ }^{18} \mathrm{~F}$. In MRI, the focus is placed on the anatomical characterization of a given nucleus [21]. ${ }^{18} \mathrm{~F}$-2-deoxyglucose (18FDG) is a glucose analog that can be imported and retained (phosphorylated) by cells, but not further metabolized. In addition, it contains a positron-emitting radioactive isotope $\left({ }^{18} \mathrm{~F}\right)$ that can be detected using PET. Thus, upon intravenous 18FDG infusion in patients, tumors can be localized by PET-MRI thanks to their increased capacity to accumulate the tracer [176]. Pharmacological GLUT1 inhibition can be monitored using 18FDG, and it results in a decreased signal [28] (Figure 4A). However, 18FDG is ineffective in evaluating tumors such as gliomas because of high background uptake in the brain, or in tumors/tumor regions where the increase in glucose metabolism is not that acute. Of the wide-ranging PET tracers, ${ }^{4-}{ }^{18} \mathrm{~F}-(2 \mathrm{~S}, 4 \mathrm{R})$ fluoroglutamine (18FGln) and $1-{ }^{11} \mathrm{C}$-acetate (11CAc) are particularly interesting [177-179]. In addition to their role as alternative PET tracers for tumor imaging, they can be used to point to more sensitive tumors to the inhibition of glutamine metabolism and ACSS2, respectively. In response to the pharmacological inhibition of glutamine uptake, the intratumoral accumulation of 18 FGln reduces $[69,177,180]$, whereas the intratumoral levels of 18FGln rise upon GLS inhibition [181] (Figure 4B,C).

MRS can detect metabolites whose concentration is above $1 \mathrm{mM}$. So only a limited subset of metabolites can be quantified in vivo using MRS. Although altered levels of some metabolites have been proposed as cancer biomarkers, to date 2HG accumulation in patients with $\mathrm{mIDH} 1 / 2$ gliomas is the only one to have shown its actual value as a noninvasive cancer-associated biomarker using MRS [21,182-185] (Figure 4D). The utility of MRS is limited by its low sensitivity, while the main drawback with ${ }^{18}$ F-based PET tracers is associated with loss of ${ }^{18} \mathrm{~F}$. Thus, ${ }^{18} \mathrm{~F}$-based PET tracers allow detection of the accumulation of the infused tracers, but not to study actual metabolism in vivo. Using hyperpolarized ${ }^{13} \mathrm{C}$ tracers results in an enhancement of the signal related to conventional MRI, while allowing measurement of the downstream products of the injected tracer [186]. We previously mentioned that many tumors show high MCT and LDH levels to sustain glycolysis. Hyperpolarized $1-{ }^{13} \mathrm{C}$-pyruvate can be taken up by cells and converted into 1${ }^{13} \mathrm{C}$-lactate. Upon hyperpolarized $1-{ }^{13} \mathrm{C}$-pyruvate infusion in patients with prostate cancer, biopsy-proven cancerous regions show increased hyperpolarized $1-{ }^{13} \mathrm{C}$-lactate levels and a high $1-{ }^{13} \mathrm{C}$-lactate $/ 1-{ }^{13} \mathrm{C}$-pyruvate ratio [187]. In preclinical models, the $1-{ }^{13} \mathrm{C}$-lactate $/ 1$ ${ }^{13} \mathrm{C}$-pyruvate ratio lowers upon chemotherapy [188] but, more interestingly, they can be used to identify tumors susceptible to LDH or MCT inhibition, and to monitor in vivo the response to targeted therapies against those key glycolysis-related proteins $[45,189,190]$ (Figure 4E). The direct measurement of the glycolysis pathway can be done instead using hyperpolarized $\mathrm{U}^{2} \mathrm{H}, \mathrm{U}-{ }^{13} \mathrm{C}$-glucose, which results in ${ }^{13} \mathrm{C}$ labeling in lactate, but also in other glucose products as the intermediate on the oxidative branch of the pentose phosphate pathway 6-phosphogluconate. Increased labeling in lactate is observed in tumors compared to adjacent normal tissue, and the signal decreases upon treatment with chemotherapy [191]. In addition to the direct 2HG measurement in gliomas with mIDH1/2, the in vivo production of $2 \mathrm{HG}$ can be measured using hyperpolarized $1-{ }^{13} \mathrm{C}-\alpha-\mathrm{KG}$ [192] or $1-{ }^{13} \mathrm{C}$-glutamine [193]. Upon the pharmacological inhibition of mIDH1, glutamine-derived 2HG production decreases [193] (Figure 4F). 
A

Increased glucose consumption is a common phenotype to many tumors. Tumors can be diagnosed by PET using 18FDG, which is rapidly taken

B The retained by pho

Tumors can be diagnosed by PET using 18FGIn, which provides better signal-to-noise than 18FDG in tissues with high glucose consumption. In addition, 18FGIn identifies tumors likely to respond to glutamine metabolism inhibitors.
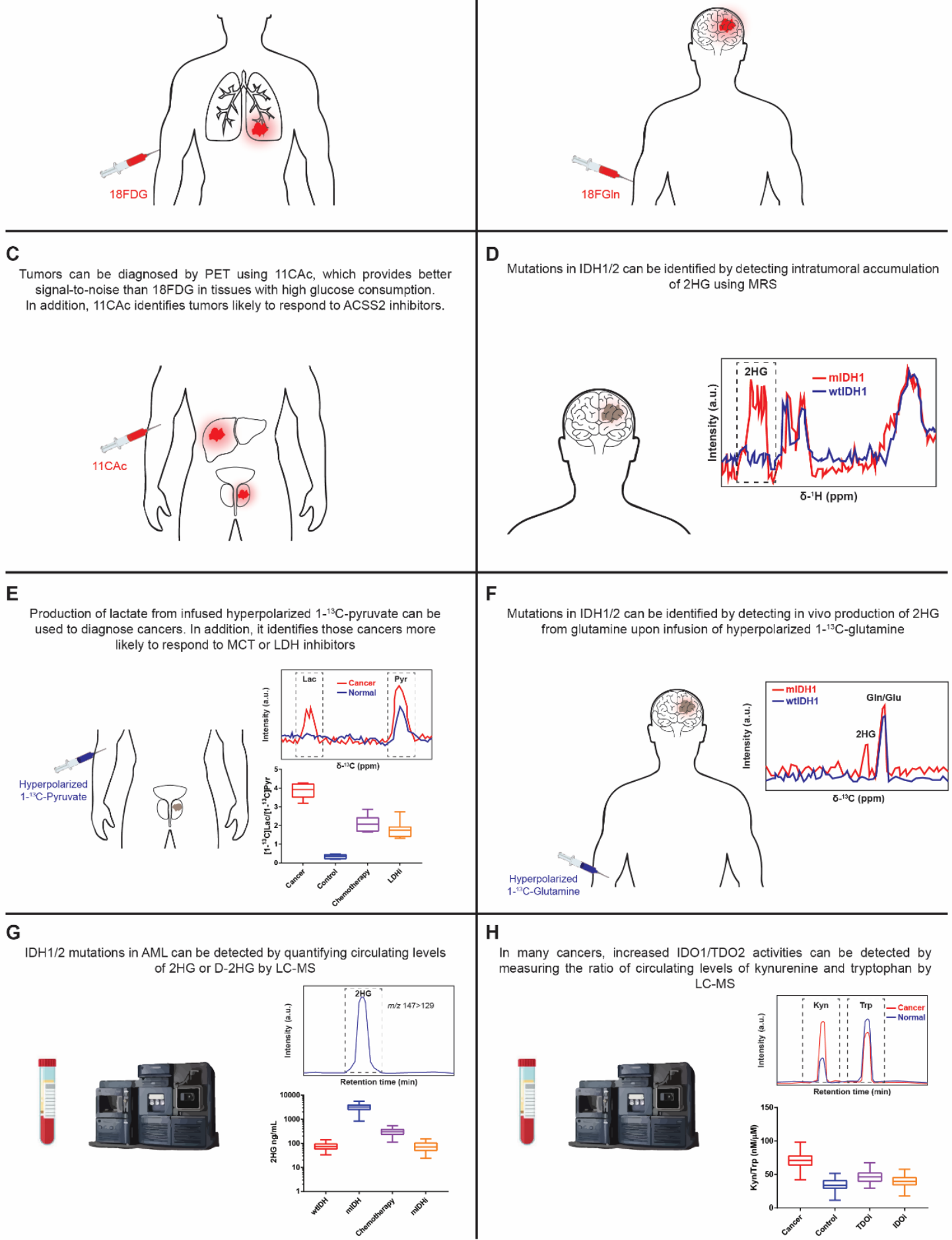

Figure 4. Metabolic activities/metabolites and the associated noninvasive techniques for their assessment with diagnostic, therapy selection and efficacy prospects. (A). PET-based detection of infused 18FDG. (B). PET-based detection of infused 18FGln. (C). PET-based detection of infused 11CAc. (D). MRS-based detection of infused 2HG. (E). MRI-based detection of 13C-Lactate produced from infused hyperpolarized 1-13C-pyruvate. (F). MRI-based detection of 13C-2HG produced from infused hyperpolarized 1-13C-glutamine. (G). LC-MS-based detection of circulating (D-)2HG. (H). LC-MS-based detection of circulating tryptophan and kynurenine. 18FDG: ${ }^{18} \mathrm{~F}-2$-deoxyglucose; $18 \mathrm{FGln}$ : $4{ }^{18} \mathrm{~F}-(2 \mathrm{~S}, 4 \mathrm{R})$-fluoroglutamine; $11 \mathrm{CAc}$ 1- ${ }^{11} \mathrm{C}$-acetate; ACSS2: acetyl-CoA synthetase 2; IDO1: indoleamine 2,3 dioxygenase 1; TDO2: tryptophan-2,3-dioxygenase 2. 


\subsection{LC-MS}

MS-based metabolomics analyses are typically performed by two complementary approaches known as untargeted and targeted metabolomics. The former aims to provide the widest possible metabolome coverage, while the latter focuses on the quantification of a pre-determined set of known metabolites [22]. In the exploratory analysis, untargeted metabolomics is key to identify altered metabolites. Proper validation and transfer to the clinic requires the development of rapid, specific, and quantitative measurements using targeted methods and different cohorts of patients from those used for biomarker discovery. To exemplify the importance of proper validation when the aim is to translate a biomarker into the clinic, using the untargeted characterization of clinical samples (including tissue, plasma and urine) sarcosine, an $\mathrm{N}$-methyl derivative of glycine, was identified as a differential metabolite that substantially increased during prostate cancer progression to metastasis and was detected non-invasively in urine [194]. However, the attempts to reproduce this observation have failed to validate sarcosine as a biomarker of prostate cancer in either serum or urine samples $[195,196]$. Conversely, (D-)2HG and IDO1/TDO2-related metabolites tryptophan and kynurenine are two examples of the successful application of LC-MS-based technology to assess metabolites as biomarkers in cancer.

D-2HG accumulation is the hallmark of tumors harboring mutations in IDH1/2 [103,104]. Albeit to a lesser extent, it can be produced by enzyme D-3-phosphoglycerate dehydrogenase (PHGDH), the first enzyme in the serine biosynthetic pathway, which is genomically amplified in various cancer types [197]. L-2HG can be produced under hypoxia or acidic conditions by enzymes LDH and malate dehydrogenase (MDH) [198,199]. However, to separate $\mathrm{D}(\mathrm{R})$ and $\mathrm{L}(\mathrm{S})$ enantiomers of $2 \mathrm{HG}$, chiral chromatographic separation (through 2HG derivatization with a chiral agent or using a chiral column) must be performed. The increase in 2HG is reflected at the systemic level, and mutations in IDH1/2 result in higher circulating levels of D- and total 2HG in AML patients. Quantification of D- or total 2HG can be used to discriminate between tumors/cancers harboring wt and $\mathrm{mIDH} 1 / 2$, and the levels of D- or total 2HG lower upon both mIDH1/2 inhibition and tumor/cancer regression [104,108,109,111,200-203] (Figure 4G).

High IDO1 levels are associated with poor prognosis in several cancer types [204]. Indeed altered serum/plasma levels of tryptophan and/or kynurenine have been found in various cancer types compared to healthy donors. [204-206]. However, the dietary influence on both tryptophan and kynurenine circulating levels hinders their usefulness as prognostic or diagnostic markers in cancer [204]. IDO1 inhibition results in low kynurenine and of kynurenine/tryptophan levels, whereas TDO2 inhibition leads to high tryptophan levels and, thus, low kynurenine/tryptophan levels. Thus, the measurement of circulating kynurenine and tryptophan levels is routinely used to assess the efficacy of IDO1 and TDO2 inhibitor efficacy in both preclinical and clinical studies [136,207-210] (Figure 4H).

In addition to quantifying small molecules, high-resolution MS allows stable isotope tracers to be used to study metabolism [23]. Although the combination of infused isotope tracers with the characterization of the produced metabolites in circulation has not yet been achieved, intraoperative infusion of isotope tracers followed by the comprehensive metabolic characterization of the resected tumor/biopsy by LC-MS-based metabolomics provides the unprecedented characterization of the in vivo metabolism of tumors. This approach has the potential to be extremely useful not only in decision making, but also in identifying new metabolic vulnerabilities [211-215].

\section{Conclusions}

Tumor metabolism and its crosstalk with the TME is an active research field. Metabolic plasticity in tumors allows their adaptation to the challenging TME conditions, and may eventually enable and support metastasis. Advances in molecular biology, genetic tools and metabolomics have greatly extended the knowledge about tumor metabolism both in vitro and in vivo. The characterization of metabolic fluxes and metabolic co-dependences across 
a wide variety of tumor types, combined with detailed information about the many cell types making up the TME, has allowed the identification of therapeutic targets whose specific aims are cancer and cancer-supporting cells, while relieving the suppression that antitumor cells suffer in the TME. Such new findings have promoted the development of a wide arsenal of antitumor drugs with the potential to be used alone or in combination with immunotherapies (i.e., immune checkpoint inhibitors, vaccines or adoptive transfer of immune cells, e.g., CAR-T cells). To take full advantage of these new developments and to select the treatment that best works for each patient, we should be able to translate these molecular characterization capabilities used in preclinical experimentation to the clinic. To this end, highly informative, yet invasive, techniques should be replaced with noninvasive ones. Recently, the use of liquid biopsy-mainly blood-for analysis of circulating tumor cells (CTCs) and circulating cell-free tumor DNA (ctDNA) has become a valuable tool to guide treatment and to monitor response to therapy [216]. With direct metabolic measurements, we name a few successful examples of MRS, MRI and PET imaging techniques and the LC-MS-based quantification of circulating metabolites (i.e., D-2HG and kynurenine/tryptophan). However, these approaches do not reproduce the complexity required for profound metabolic characterization and each one only informs about a particular or a very narrow set of metabolic activities. Only by understanding how tumor cells alter circulating metabolites concentrations and how cancer metabolism of infused stable isotopic tracers can be reconstructed from circulating metabolites will we be able to fully unleash the potential of metabolic-based determinations and treatments to guide personalized medicine into the clinic. Hence, LC-MS-based-metabolomics alongside other clinical analyses will soon play an increasingly key role.

Author Contributions: J.C.G.-C. and A.L. conceived, wrote and edited the manuscript. All authors have read and agreed to the published version of the manuscript.

Funding: J.C.G.-C. is supported by a grant from the Conselleria de Sanidad Universal y Salud Pública, Generalitat Valenciana, as part of Plan GenT, Generació Talent (DEI-01/20-C) and grant GIDO Research Project 2021. A.L. is supported by the European Regional Development Fund (FEDER), and the Carlos III Health Institute of the Spanish Ministry of Economy and Competitiveness (PI20/00580).

Institutional Review Board Statement: Not applicable.

Informed Consent Statement: Not applicable.

Data Availability Statement: No new data were created or analyzed in this study.

Conflicts of Interest: The authors declare no conflict of interest.

\section{References}

1. Warburg, O.; Wind, F.; Negelein, E. The metabolism of tumors in the body. J. Gen. Physiol. 1927, 8, 519-530. [CrossRef]

2. Pavlova, N.N.; Thompson, C.B. The Emerging Hallmarks of Cancer Metabolism. Cell Metab. 2016, 23, 27-47. [CrossRef] [PubMed]

3. De Berardinis, R.J.; Chandel, N.S. Fundamentals of cancer metabolism. Sci. Adv. 2016, 2, e1600200. [CrossRef] [PubMed]

4. Faubert, B.; Solmonson, A.; DeBerardinis, R.J. Metabolic reprogramming and cancer progression. Science 2020, 368 , eaaw5473. [CrossRef]

5. Dey, P.; Kimmelman, A.C.; DePinho, R.A. Metabolic Codependencies in the Tumor Microenvironment. Cancer Discov. 2021, 11, 1067-1081. [CrossRef]

6. Egeblad, M.; Nakasone, E.S.; Werb, Z. Tumors as organs: Complex tissues that interface with the entire organism. Dev. Cell 2010, 18, 884-901. [CrossRef] [PubMed]

7. Hanahan, D.; Coussens, L.M. Accessories to the Crime: Functions of Cells Recruited to the Tumor Microenvironment. Cancer Cell 2012, 21, 309-322. [CrossRef] [PubMed]

8. Vander Heiden, M.G.; DeBerardinis, R.J. Understanding the Intersections between Metabolism and Cancer Biology. Cell 2017, 168, 657-669. [CrossRef]

9. Yuneva, M.O.; Fan, T.W.M.; Allen, T.D.; Higashi, R.M.; Ferraris, D.V.; Tsukamoto, T.; Matés, J.M.; Alonso, F.J.; Wang, C.; Seo, Y.; et al. The metabolic profile of tumors depends on both the responsible genetic lesion and tissue type. Cell Metab. 2012, 15, 157-170. [CrossRef] 
10. Davidson, S.M.; Papagiannakopoulos, T.; Olenchock, B.A.; Heyman, J.E.; Keibler, M.A.; Luengo, A.; Bauer, M.R.; Jha, A.K.; O'Brien, J.P.; Pierce, K.A.; et al. Environment impacts the metabolic dependencies of ras-driven non-small cell lung cancer. Cell Metab. 2016, 23, 517-528. [CrossRef]

11. García-Canaveras, J.C.; Chen, L.; Rabinowitz, J.D. The tumor metabolic microenvironment: Lessons from lactate. Cancer Res. 2019, 79, 3155-31162. [CrossRef] [PubMed]

12. Méndez-Lucas, A.; Lin, W.; Driscoll, P.C.; Legrave, N.; Novellasdemunt, L.; Xie, C.; Charles, M.; Wilson, Z.; Jones, N.P.; Rayport, S.; et al. Identifying strategies to target the metabolic flexibility of tumours. Nat. Metab. 2020, 2, 335-350. [CrossRef] [PubMed]

13. Andrejeva, G.; Rathmell, J.C. Similarities and Distinctions of Cancer and Immune Metabolism in Inflammation and Tumors. Cell Metab. 2017, 26, 49-70. [CrossRef]

14. Buck, M.D.; Sowell, R.T.; Kaech, S.M.; Pearce, E.L. Metabolic Instruction of Immunity. Cell 2017, 169, 570-586. [CrossRef]

15. Yang, L.; Achreja, A.; Yeung, T.L.; Mangala, L.S.; Jiang, D.; Han, C.; Baddour, J.; Marini, J.C.; Ni, J.; Nakahara, R.; et al. Targeting Stromal Glutamine Synthetase in Tumors Disrupts Tumor Microenvironment-Regulated Cancer Cell Growth. Cell Metab. 2016, 24, 685-700. [CrossRef]

16. Nieman, K.M.; Kenny, H.A.; Penicka, C.V.; Ladanyi, A.; Buell-Gutbrod, R.; Zillhardt, M.R.; Romero, I.L.; Carey, M.S.; Mills, G.B.; Hotamisligil, G.S.; et al. Adipocytes promote ovarian cancer metastasis and provide energy for rapid tumor growth. Nat. Med. 2011, 17, 1498-1503. [CrossRef]

17. Sousa, C.M.; Biancur, D.E.; Wang, X.; Halbrook, C.J.; Sherman, M.H.; Zhang, L.; Kremer, D.; Hwang, R.F.; Witkiewicz, A.K.; Ying, H.; et al. Pancreatic stellate cells support tumour metabolism through autophagic alanine secretion. Nature 2016, 536, 479-483. [CrossRef] [PubMed]

18. Lyssiotis, C.A.; Kimmelman, A.C. Metabolic Interactions in the Tumor Microenvironment. Trends Cell Biol. 2017, $27,863-875$. [CrossRef]

19. Sugiura, A.; Rathmell, J.C. Metabolic Barriers to T Cell Function in Tumors. J. Immunol. 2018, 200, 400-407. [CrossRef]

20. Farber, S.; Diamond, L.K.; Mercer, R.D.; Sylvester, R.F.; Wolff, J.A. Temporary Remissions in Acute Leukemia in Children Produced by Folic Acid Antagonist, 4-Aminopteroyl-Glutamic Acid (Aminopterin). N. Engl. J. Med. 1948, 238, 787-793. [CrossRef]

21. Faubert, B.; DeBerardinis, R.J. Analyzing Tumor Metabolism In Vivo. Annu. Rev. Cancer Biol. 2017, 1, 99-117. [CrossRef]

22. Roca, M.; Alcoriza, M.I.; Garcia-Cañaveras, J.C.; Lahoz, A. Reviewing the metabolome coverage provided by LC-MS: Focus on sample preparation and chromatography-A tutorial. Anal. Chim. Acta 2021, 1147, 38-55. [CrossRef]

23. Jang, C.; Chen, L.; Rabinowitz, J.D. Metabolomics and Isotope Tracing. Cell 2018, 173, 822-837. [CrossRef] [PubMed]

24. Xi, H.; Kurtoglu, M.; Lampidis, T.J. The wonders of 2-deoxy-d-glucose. IUBMB Life 2014, 66, 110-121. [CrossRef] [PubMed]

25. Galluzzi, L.; Kepp, O.; Heiden, M.G.V.; Kroemer, G. Metabolic targets for cancer therapy. Nat. Rev. Drug Discov. 2013, 12, 829-846. [CrossRef]

26. Tennant, D.A.; Durán, R.V.; Gottlieb, E. Targeting metabolic transformation for cancer therapy. Nat. Rev. Cancer 2010, 10, 267-277. [CrossRef]

27. Siebeneicher, H.; Cleve, A.; Rehwinkel, H.; Neuhaus, R.; Heisler, I.; Müller, T.; Bauser, M.; Buchmann, B. Identification and Optimization of the First Highly Selective GLUT1 Inhibitor BAY-876. ChemMedChem 2016, 11, 2261-2271. [CrossRef]

28. Chan, D.A.; Sutphin, P.D.; Nguyen, P.; Turcotte, S.; Lai, E.W.; Banh, A.; Reynolds, G.E.; Chi, J.T.; Wu, J.; Solow-Cordero, D.E.; et al. Targeting GLUT1 and the Warburg effect in renal cell carcinoma by chemical synthetic lethality. Sci. Transl. Med. 2011, 3. [CrossRef]

29. Liu, Y.; Cao, Y.; Zhang, W.; Bergmeier, S.; Qian, Y.; Akbar, H.; Colvin, R.; Ding, J.; Tong, L.; Wu, S.; et al. A small-molecule inhibitor of glucose transporter 1 downregulates glycolysis, induces cell-cycle arrest, and inhibits cancer cell growth in vitro and in vivo. Mol. Cancer Ther. 2012, 11, 1672-1682. [CrossRef]

30. Reckzeh, E.S.; Karageorgis, G.; Schwalfenberg, M.; Ceballos, J.; Nowacki, J.; Stroet, M.C.M.; Binici, A.; Knauer, L.; Brand, S.; Choidas, A.; et al. Inhibition of Glucose Transporters and Glutaminase Synergistically Impairs Tumor Cell Growth. Cell Chem. Biol. 2019, 26, 1214-1228.e25. [CrossRef]

31. Ma, Y.; Wang, W.; Idowu, M.O.; Oh, U.; Wang, X.Y.; Temkin, S.M.; Fang, X. Ovarian cancer relies on glucose transporter 1 to fuel glycolysis and growth: Anti-tumor activity of BAY-876. Cancers 2019, 11, 33. [CrossRef]

32. Birsoy, K.; Wang, T.; Chen, W.W.; Freinkman, E.; Abu-Remaileh, M.; Sabatini, D.M. An Essential Role of the Mitochondrial Electron Transport Chain in Cell Proliferation Is to Enable Aspartate Synthesis. Cell 2015, 162, 540-551. [CrossRef] [PubMed]

33. Sullivan, L.B.; Gui, D.Y.; Hosios, A.M.; Bush, L.N.; Freinkman, E.; Vander Heiden, M.G. Supporting Aspartate Biosynthesis Is an Essential Function of Respiration in Proliferating Cells. Cell 2015, 162, 552-563. [CrossRef] [PubMed]

34. Titov, D.V.; Cracan, V.; Goodman, R.P.; Peng, J.; Grabarek, Z.; Mootha, V.K. Complementation of mitochondrial electron transport chain by manipulation of the NAD+/NADH ratio. Science 2016, 352, 231-235. [CrossRef] [PubMed]

35. Luengo, A.; Li, Z.; Gui, D.Y.; Sullivan, L.B.; Zagorulya, M.; Do, B.T.; Ferreira, R.; Naamati, A.; Ali, A.; Lewis, C.A.; et al. Increased demand for NAD+ relative to ATP drives aerobic glycolysis. Mol. Cell 2021, 81, 691-707.e6. [CrossRef]

36. Murray, C.M.; Hutchinson, R.; Bantick, J.R.; Belfield, G.P.; Benjamin, A.D.; Brazma, D.; Bundick, R.V.; Cook, I.D.; Craggs, R.I.; Edwards, S.; et al. Monocarboxylate Transporter Mctl is a Target for Immunosuppression. Nat. Chem. Biol. 2005, 1, 371-376. [CrossRef] 
37. Guile, S.D.; Bantick, J.R.; Cooper, M.E.; Donald, D.K.; Eyssade, C.; Ingall, A.H.; Lewis, R.J.; Martin, B.P.; Mohammed, R.T.; Potter, T.J.; et al. Optimization of monocarboxylate transporter 1 blockers through analysis and modulation of atropisomer interconversion properties. J. Med. Chem. 2007, 50, 254-263. [CrossRef]

38. Quanz, M.; Bender, E.; Kopitz, C.; Grünewald, S.; Schlicker, A.; Schwede, W.; Eheim, A.; Toschi, L.; Neuhaus, R.; Richter, C.; et al. Preclinical efficacy of the novel monocarboxylate transporter 1 inhibitor BAY-8002 and associated markers of resistance. Mol. Cancer Ther. 2018, 17, 2285-2296. [CrossRef]

39. Polanski, R.; Hodgkinson, C.L.; Fusi, A.; Nonaka, D.; Priest, L.; Kelly, P.; Trapani, F.; Bishop, P.W.; White, A.; Critchlow, S.E.; et al. Activity of the monocarboxylate transporter 1 inhibitor azd3965 in small cell lung cancer. Clin. Cancer Res. 2014, $20,926-937$. [CrossRef]

40. Doherty, J.R.; Yang, C.; Scott, K.E.N.; Cameron, M.D.; Fallahi, M.; Li, W.; Hall, M.A.; Amelio, A.L.; Mishra, J.K.; Li, F.; et al. Blocking lactate export by inhibiting the myc target MCT1 disables glycolysis and glutathione synthesis. Cancer Res. 2014, 74, 908-920. [CrossRef]

41. Le Floch, R.; Chiche, J.; Marchiq, I.; Naiken, T.; Ilc, K.; Murray, C.M.; Critchlow, S.E.; Roux, D.; Simon, M.-P.; Pouyssegur, J. CD147 subunit of lactate/H+ symporters MCT1 and hypoxia-inducible MCT4 is critical for energetics and growth of glycolytic tumors. Proc. Natl. Acad. Sci. USA 2011, 108, 16663-16668. [CrossRef]

42. Benjamin, D.; Robay, D.; Hindupur, S.K.; Pohlmann, J.; Colombi, M.; El-Shemerly, M.Y.; Maira, S.M.; Moroni, C.; Lane, H.A.; Hall, M.N. Dual Inhibition of the Lactate Transporters MCT1 and MCT4 Is Synthetic Lethal with Metformin due to NAD+ Depletion in Cancer Cells. Cell Rep. 2018, 25, 3047-3058.e4. [CrossRef] [PubMed]

43. Le, A.; Cooper, C.R.; Gouw, A.M.; Dinavahi, R.; Maitra, A.; Deck, L.M.; Royer, R.E.; Vander Jagt, D.L.; Semenza, G.L.; Dang, C.V. Inhibition of lactate dehydrogenase A induces oxidative stress and inhibits tumor progression. Proc. Natl. Acad. Sci. USA 2010, 107, 2037-2042. [CrossRef]

44. Rai, G.; Brimacombe, K.R.; Mott, B.T.; Urban, D.J.; Hu, X.; Yang, S.M.; Lee, T.D.; Cheff, D.M.; Kouznetsova, J.; Benavides, G.A.; et al. Discovery and Optimization of Potent, Cell-Active Pyrazole-Based Inhibitors of Lactate Dehydrogenase (LDH). J. Med. Chem. 2017, 60, 9184-9204. [CrossRef]

45. Oshima, N.; Ishida, R.; Kishimoto, S.; Beebe, K.; Brender, J.R.; Yamamoto, K.; Urban, D.; Rai, G.; Johnson, M.S.; Benavides, G.; et al. Dynamic Imaging of LDH Inhibition in Tumors Reveals Rapid In Vivo Metabolic Rewiring and Vulnerability to Combination Therapy. Cell Rep. 2020, 30, 1798-1810.e4. [CrossRef]

46. Yeung, C.; Gibson, A.E.; Issaq, S.H.; Oshima, N.; Baumgart, J.T.; Edessa, L.D.; Rai, G.; Urban, D.J.; Johnson, M.S.; Benavides, G.A.; et al. Targeting glycolysis through inhibition of lactate dehydrogenase impairs tumor growth in preclinical models of Ewing sarcoma. Cancer Res. 2019, 79, 5060-5073. [CrossRef]

47. Beloueche-Babari, M.; Wantuch, S.; Galobart, T.C.; Koniordou, M.; Parkes, H.G.; Arunan, V.; Chung, Y.L.; Eykyn, T.R.; Smith, P.D.; Leach, M.O. MCT1 inhibitor AZD3965 increases mitochondrial metabolism, facilitating combination therapy and noninvasive magnetic resonance spectroscopy. Cancer Res. 2017, 77, 5913-5924. [CrossRef]

48. Weinberg, S.E.; Chandel, N.S. Targeting mitochondria metabolism for cancer therapy. Nat. Chem. Biol. 2015, 11, 9-15. [CrossRef] [PubMed]

49. Molina, J.R.; Sun, Y.; Protopopova, M.; Gera, S.; Bandi, M.; Bristow, C.; McAfoos, T.; Morlacchi, P.; Ackroyd, J.; Agip, A.N.A.; et al. An inhibitor of oxidative phosphorylation exploits cancer vulnerability. Nat. Med. 2018, 24, 1036-1046. [CrossRef] [PubMed]

50. Wheaton, W.W.; Weinberg, S.E.; Hamanaka, R.B.; Soberanes, S.; Sullivan, L.B.; Anso, E.; Glasauer, A.; Dufour, E.; Mutlu, G.M.; Scott Budigner, G.R.; et al. Metformin inhibits mitochondrial complex I of cancer cells to reduce tumorigenesis. eLife 2014, 2014, 1-18. [CrossRef] [PubMed]

51. Andrzejewski, S.; Gravel, S.-P.; Pollak, M.; St-Pierre, J. Metformin directly acts on mitochondria to alter cellular bioenergetics. Cancer Metab. 2014, 2, 12. [CrossRef] [PubMed]

52. Garcia-Bermudez, J.; Baudrier, L.; La, K.; Zhu, X.G.; Fidelin, J.; Sviderskiy, V.O.; Papagiannakopoulos, T.; Molina, H.; Snuderl, M.; Lewis, C.A.; et al. Aspartate is a limiting metabolite for cancer cell proliferation under hypoxia and in tumours. Nat. Cell Biol. 2018, 20, 775-781. [CrossRef] [PubMed]

53. Sullivan, L.B.; Luengo, A.; Danai, L.V.; Bush, L.N.; Diehl, F.F.; Hosios, A.M.; Lau, A.N.; Elmiligy, S.; Malstrom, S.; Lewis, C.A.; et al. Aspartate is an endogenous metabolic limitation for tumour growth. Nat. Cell Biol. 2018, 20, 782-788. [CrossRef]

54. Gui, D.Y.; Sullivan, L.B.; Luengo, A.; Hosios, A.M.; Bush, L.N.; Gitego, N.; Davidson, S.M.; Freinkman, E.; Thomas, C.J.; Vander Heiden, M.G. Environment Dictates Dependence on Mitochondrial Complex I for NAD+ and Aspartate Production and Determines Cancer Cell Sensitivity to Metformin. Cell Metab. 2016, 24, 716-727. [CrossRef]

55. Hensley, C.T.; Wasti, A.T.; DeBerardinis, R.J. Glutamine and cancer: Cell biology, physiology, and clinical opportunities. J. Clin. Investig. 2013, 123, 3678-3684. [CrossRef]

56. Yang, L.; Venneti, S.; Nagrath, D. Glutaminolysis: A Hallmark of Cancer Metabolism. Annu. Rev. Biomed. Eng. 2017, 19, 163-194. [CrossRef]

57. Lemberg, K.M.; Vornov, J.J.; Rais, R.; Slusher, B.S. We're not “don" yet: Optimal dosing and prodrug delivery of 6-diazo-5-oxo-Lnorleucine. Mol. Cancer Ther. 2018, 17, 1824-1832. [CrossRef]

58. Rais, R.; Jančařík, A.; Tenora, L.; Nedelcovych, M.; Alt, J.; Englert, J.; Rojas, C.; Le, A.; Elgogary, A.; Tan, J.; et al. Discovery of 6-Diazo-5-oxo-l-norleucine (DON) Prodrugs with Enhanced CSF Delivery in Monkeys: A Potential Treatment for Glioblastoma. J. Med. Chem. 2016, 59, 8621-8633. [CrossRef] [PubMed] 
59. Leone, R.D.; Zhao, L.; Englert, J.M.; Sun, I.M.; Oh, M.H.; Sun, I.H.; Arwood, M.L.; Bettencourt, I.A.; Patel, C.H.; Wen, J.; et al. Glutamine blockade induces divergent metabolic programs to overcome tumor immune evasion. Science 2019, 366, $1013-1021$. [CrossRef]

60. Gross, M.I.; Demo, S.D.; Dennison, J.B.; Chen, L.; Chernov-Rogan, T.; Goyal, B.; Janes, J.R.; Laidig, G.J.; Lewis, E.R.; Li, J.; et al. Antitumor Activity of the Glutaminase Inhibitor CB-839 in Triple-Negative Breast Cancer. Mol. Cancer Ther. 2014, 13, 890-901. [CrossRef]

61. Le, A.; Lane, A.N.; Hamaker, M.; Bose, S.; Gouw, A.; Barbi, J.; Tsukamoto, T.; Rojas, C.J.; Slusher, B.S.; Zhang, H.; et al. Glucoseindependent glutamine metabolism via TCA cycling for proliferation and survival in b cells. Cell Metab. 2012, 15, 110-121. [CrossRef]

62. Wang, J.B.; Erickson, J.W.; Fuji, R.; Ramachandran, S.; Gao, P.; Dinavahi, R.; Wilson, K.F.; Ambrosio, A.L.B.; Dias, S.M.G.; Dang, C.V.; et al. Targeting mitochondrial glutaminase activity inhibits oncogenic transformation. Cancer Cell 2010, 18, 207-219. [CrossRef] [PubMed]

63. Son, J.; Lyssiotis, C.A.; Ying, H.; Wang, X.; Hua, S.; Ligorio, M.; Perera, R.M.; Ferrone, C.R.; Mullarky, E.; Shyh-Chang, N.; et al. Glutamine supports pancreatic cancer growth through a KRAS-regulated metabolic pathway. Nature 2013, 496, 101-105. [CrossRef] [PubMed]

64. Xiang, Y.; Stine, Z.E.; Xia, J.; Lu, Y.; O'Connor, R.S.; Altman, B.J.; Hsieh, A.L.; Gouw, A.M.; Thomas, A.G.; Gao, P.; et al. Targeted inhibition of tumor-specific glutaminase diminishes cell-autonomous tumorigenesis. J. Clin. Investig. 2015, 125, $2293-2306$. [CrossRef]

65. Varghese, S.; Pramanik, S.; Williams, L.J.; Hodges, H.R.; Hudgens, C.W.; Fischer, G.M.; Luo, C.K.; Knighton, B.; Tan, L.; Lorenzi, P.L.; et al. The glutaminase inhibitor CB-839 (Telaglenastat) enhances the antimelanoma activity of T-cell-mediated immunotherapies. Mol. Cancer Ther. 2021, 20, 500-511. [CrossRef] [PubMed]

66. Willems, L.; Jacque, N.; Jacquel, A.; Neveux, N.; Maciel, T.T.; Lambert, M.; Schmitt, A.; Poulain, L.; Green, A.S.; Uzunov, M.; et al. Inhibiting Glutamine uptake represents an attractive new strategy for treating acute myeloid leukemia. Blood 2013, 122, 3521-3532. [CrossRef]

67. Hassanein, M.; Qian, J.; Hoeksema, M.D.; Wang, J.; Jacobovitz, M.; Ji, X.; Harris, F.T.; Harris, B.K.; Boyd, K.L.; Chen, H.; et al. Targeting SLC1a5-mediated glutamine dependence in non-small cell lung cancer. Int. J. Cancer 2015, 137, 1587-1597. [CrossRef]

68. Hassanein, M.; Hoeksema, M.D.; Shiota, M.; Qian, J.; Harris, B.K.; Chen, H.; Clark, J.E.; Alborn, W.E.; Eisenberg, R.; Massion, P.P. SLC1A5 mediates glutamine transport required for lung cancer cell growth and survival. Clin. Cancer Res. 2013, 19, 560-570. [CrossRef]

69. Schulte, M.L.; Fu, A.; Zhao, P.; Li, J.; Geng, L.; Smith, S.T.; Kondo, J.; Coffey, R.J.; Johnson, M.O.; Rathmell, J.C.; et al. Pharmacological blockade of ASCT2-dependent glutamine transport leads to antitumor efficacy in preclinical models. Nat. Med. 2018, 24, 194-202. [CrossRef] [PubMed]

70. Broadfield, L.A.; Pane, A.A.; Talebi, A.; Swinnen, J.V.; Fendt, S. Lipid metabolism in cancer: New perspectives and emerging mechanisms. Dev. Cell 2021, 56, 1363-1393. [CrossRef]

71. Ladanyi, A.; Mukherjee, A.; Kenny, H.A.; Johnson, A.; Mitra, A.K.; Sundaresan, S.; Nieman, K.M.; Pascual, G.; Benitah, S.A.; Montag, A.; et al. Adipocyte-induced CD36 expression drives ovarian cancer progression and metastasis. Oncogene 2018, 37, 2285-2301. [CrossRef]

72. Wen, Y.A.; Xing, X.; Harris, J.W.; Zaytseva, Y.Y.; Mitov, M.I.; Napier, D.L.; Weiss, H.L.; Mark Evers, B.; Gao, T. Adipocytes activate mitochondrial fatty acid oxidation and autophagy to promote tumor growth in colon cancer. Cell Death Dis. 2017, 8, 1-12. [CrossRef]

73. Camarda, R.; Zhou, A.Y.; Kohnz, R.A.; Balakrishnan, S.; Mahieu, C.; Anderton, B.; Eyob, H.; Kajimura, S.; Tward, A.; Krings, G.; et al. Inhibition of fatty acid oxidation as a therapy for MYC-overexpressing triple-negative breast cancer. Nat. Med. 2016, 22, 427-432. [CrossRef]

74. Wang, Y.Y.; Attané, C.; Milhas, D.; Dirat, B.; Dauvillier, S.; Guerard, A.; Gilhodes, J.; Lazar, I.; Alet, N.; Laurent, V.; et al. Mammary adipocytes stimulate breast cancer invasion through metabolic remodeling of tumor cells. J. Clin. Investig. 2017, 2. [CrossRef]

75. Padanad, M.S.; Konstantinidou, G.; Venkateswaran, N.; Melegari, M.; Rindhe, S.; Mitsche, M.; Yang, C.; Batten, K.; Huffman, K.E.; Liu, J.; et al. Fatty Acid Oxidation Mediated by Acyl-CoA Synthetase Long Chain 3 Is Required for Mutant KRAS Lung Tumorigenesis. Cell Rep. 2016, 16, 1614-1628. [CrossRef]

76. Pascual, G.; Avgustinova, A.; Mejetta, S.; Martín, M.; Castellanos, A.; Attolini, C.S.O.; Berenguer, A.; Prats, N.; Toll, A.; Hueto, J.A.; et al. Targeting metastasis-initiating cells through the fatty acid receptor CD36. Nature 2017, 541, 41-45. [CrossRef]

77. Yang, P.; Su, C.; Luo, X.; Zeng, H.; Zhao, L.; Wei, L.; Zhang, X.; Varghese, Z.; Moorhead, J.F.; Chen, Y.; et al. Dietary oleic acid-induced CD36 promotes cervical cancer cell growth and metastasis via up-regulation Src/ERK pathway. Cancer Lett. 2018, 438, 76-85. [CrossRef] [PubMed]

78. Gong, J.; Lin, Y.; Zhang, H.; Liu, C.; Cheng, Z.; Yang, X.; Zhang, J.; Xiao, Y.; Sang, N.; Qian, X.; et al. Reprogramming of lipid metabolism in cancer-associated fibroblasts potentiates migration of colorectal cancer cells. Cell Death Dis. 2020, 11, 1-15. [CrossRef]

79. Wang, H.; Franco, F.; Tsui, Y.; Xie, X.; Trefny, M.P.; Zappasodi, R.; Mohmood, S.R.; Fernández-García, J.; Tsai, C.; Schulze, I.; et al. CD36-mediated metabolic adaptation supports regulatory T cell survival and function in tumors. Nat. Immunol. 2020, 21, 298-308. [CrossRef] [PubMed] 
80. Michalek, R.D.; Gerriets, V.A.; Jacobs, S.R.; Macintyre, A.N.; MacIver, N.J.; Mason, E.F.; Sullivan, S.A.; Nichols, A.G.; Rathmell, J.C. Cutting Edge: Distinct Glycolytic and Lipid Oxidative Metabolic Programs Are Essential for Effector and Regulatory CD4 ${ }^{+} \mathrm{T}$ Cell Subsets. J. Immunol. 2011, 186, 3299-3303. [CrossRef] [PubMed]

81. Hossain, F.; Al-Khami, A.A.; Wyczechowska, D.; Hernandez, C.; Zheng, L.; Reiss, K.; Del Valle, L.; Trillo-Tinoco, J.; Maj, T.; Zou, W.; et al. Inhibition of Fatty Acid Oxidation Modulates Immunosuppressive Functions of Myeloid-Derived Suppressor Cells and Enhances Cancer Therapies. Cancer Immunol. Res. 2015, 3, 1236-1247. [CrossRef] [PubMed]

82. Huang, S.C.C.; Everts, B.; Ivanova, Y.; O'Sullivan, D.; Nascimento, M.; Smith, A.M.; Beatty, W.; Love-Gregory, L.; Lam, W.Y.; O'Neill, C.M.; et al. Cell-intrinsic lysosomal lipolysis is essential for alternative activation of macrophages. Nat. Immunol. 2014, 15, 846-855. [CrossRef]

83. Schlaepfer, I.R.; Rider, L.; Rodrigues, L.U.; Gijón, M.A.; Pac, C.T.; Romero, L.; Cimic, A.; Sirintrapun, S.J.; Glodé, L.M.; Eckel, R.H.; et al. Lipid catabolism via CPT1 as a therapeutic target for prostate cancer. Mol. Cancer Ther. 2014, 13, 2361-2371. [CrossRef] [PubMed]

84. Samudio, I.; Harmancey, R.; Fiegl, M.; Kantarjian, H.; Konopleva, M.; Korchin, B.; Kaluarachchi, K.; Bornmann, W.; Duvvuri, S.; Taegtmeyer, H.; et al. Pharmacologic inhibition of fatty acid oxidation sensitizes human leukemia cells to apoptosis induction. J. Clin. Investig. 2010, 120, 142-156. [CrossRef] [PubMed]

85. Raud, B.; Roy, D.G.; Divakaruni, A.S.; Tarasenko, T.N.; Franke, R.; Ma, E.H.; Samborska, B.; Hsieh, W.Y.; Wong, A.H.; Stüve, P.; et al. Etomoxir Actions on Regulatory and Memory T Cells Are Independent of Cpt1a-Mediated Fatty Acid Oxidation. Cell Metab. 2018, 28, 504-515.e7. [CrossRef] [PubMed]

86. Yao, C.H.; Liu, G.Y.; Wang, R.; Moon, S.H.; Gross, R.W.; Patti, G.J. Identifying off-target effects of etomoxir reveals that carnitine palmitoyltransferase $\mathrm{i}$ is essential for cancer cell proliferation independent of $\beta$-oxidation. PLoS Biol. 2018, 16, 1-26. [CrossRef]

87. O'Connor, R.S.; Guo, L.; Ghassemi, S.; Snyder, N.W.; Worth, A.J.; Weng, L.; Kam, Y.; Philipson, B.; Trefely, S.; Nunez-Cruz, S.; et al. The CPT1a inhibitor, etomoxir induces severe oxidative stress at commonly used concentrations. Sci. Rep. 2018, 8, 1-9. [CrossRef]

88. Ringel, A.E.; Drijvers, J.M.; Baker, G.J.; Catozzi, A.; García-Cañaveras, J.C.; Gassaway, B.M.; Miller, B.C.; Juneja, V.R.; Nguyen, T.H.; Joshi, S.; et al. Obesity Shapes Metabolism in the Tumor Microenvironment to Suppress Anti-Tumor Immunity. Cell 2020, 183, 1848-1866.e26. [CrossRef]

89. Zhang, Y.; Kurupati, R.; Liu, L.; Zhou, X.Y.; Zhang, G.; Hudaihed, A.; Filisio, F.; Giles-Davis, W.; Xu, X.; Karakousis, G.C.; et al. Enhancing CD8+T Cell Fatty Acid Catabolism within a Metabolically Challenging Tumor Microenvironment Increases the Efficacy of Melanoma Immunotherapy. Cancer Cell 2017, 32, 377-391.e9. [CrossRef]

90. Comerford, S.A.; Huang, Z.; Du, X.; Wang, Y.; Cai, L.; Witkiewicz, A.K.; Walters, H.; Tantawy, M.N.; Fu, A.; Manning, H.C.; et al. Acetate dependence of tumors. Cell 2014, 159, 1591-1602. [CrossRef]

91. Mashimo, T.; Pichumani, K.; Vemireddy, V.; Hatanpaa, K.J.; Singh, D.K.; Sirasanagandla, S.; Nannepaga, S.; Piccirillo, S.G.; Kovacs, Z.; Foong, C.; et al. Acetate is a bioenergetic substrate for human glioblastoma and brain metastases. Cell 2014, 159, 1603-1614. [CrossRef] [PubMed]

92. Schug, Z.T.; Peck, B.; Jones, D.T.; Zhang, Q.; Grosskurth, S.; Alam, I.S.; Goodwin, L.M.; Smethurst, E.; Mason, S.; Blyth, K.; et al. Acetyl-CoA synthetase 2 promotes acetate utilization and maintains cancer cell growth under metabolic stress. Cancer Cell 2015, 27, 57-71. [CrossRef]

93. Miller, K.D.; Pniewski, K.; Perry, C.E.; Papp, S.B.; Shaffer, J.D.; Velasco-Silva, J.N.; Casciano, J.C.; Aramburu, T.M.; Srikanth, Y.V.V.; Cassel, J.; et al. Targeting ACSS2 with a transition-state mimetic inhibits triple-negative breast cancer growth. Cancer Res. 2021, 81, 1252-1264. [CrossRef] [PubMed]

94. Li, Z.; Liu, H.; He, J.; Wang, Z.; Yin, Z.; You, G.; Wang, Z.; Davis, R.E.; Lin, P.; Bergsagel, P.L.; et al. Acetyl-CoA Synthetase 2: A Critical Linkage in Obesity-Induced Tumorigenesis in Myeloma. Cell Metab. 2021, 33, 78-93.e7. [CrossRef]

95. Miller, K.D.; Schug, Z.T. Targeting acetate metabolism: Achilles' nightmare. Br. J. Cancer 2021, 124, 1900-1901. [CrossRef] [PubMed]

96. Hosios, A.M.; Hecht, V.C.; Danai, L.V.; Johnson, M.O.; Rathmell, J.C.; Steinhauser, M.L.; Manalis, S.R.; Vander Heiden, M.G. Amino Acids Rather than Glucose Account for the Majority of Cell Mass in Proliferating Mammalian Cells. Dev. Cell 2016, 36, 540-549. [CrossRef]

97. Mayers, J.R.; Torrence, M.E.; Danai, L.V.; Davidson, S.M.; Bauer, M.R.; Lau, A.N.; Ji, W.; Dixit, P.D.; Hosios, A.M.; Muir, A.; et al. Tissue-of-origin Dictates Branched-Chain Amino Acid Metabolism in Mutant Kras -driven Cancers. Science 2017, 353, 1161-1165. [CrossRef] [PubMed]

98. Hattori, A.; Tsunoda, M.; Konuma, T.; Kobayashi, M.; Nagy, T.; Glushka, J.; Tayyari, F.; McSkimming, D.; Kannan, N.; Tojo, A.; et al. Cancer progression by reprogrammed BCAA metabolism in myeloid leukaemia. Nature 2017, 545, 500-504. [CrossRef]

99. Li, J.T.; Yin, M.; Wang, D.; Wang, J.; Lei, M.Z.; Zhang, Y.; Liu, Y.; Zhang, L.; Zou, S.W.; Hu, L.P.; et al. BCAT2-mediated BCAA catabolism is critical for development of pancreatic ductal adenocarcinoma. Nat. Cell Biol. 2020, 22, 167-174. [CrossRef]

100. Tönjes, M.; Barbus, S.; Park, Y.J.; Wang, W.; Schlotter, M.; Lindroth, A.M.; Pleier, S.V.; Bai, A.H.C.; Karra, D.; Piro, R.M.; et al. BCAT1 promotes cell proliferation through amino acid catabolism in gliomas carrying wild-type IDH1. Nat. Med. 2013, 19, 901-908. [CrossRef]

101. Spinelli, J.B.; Yoon, H.; Ringel, A.E.; Jeanfavre, S.; Clish, C.B.; Haigis, M.C. Metabolic recycling of ammonia via glutamate dehydrogenase supports breast cancer biomass. Science 2017, 358, 941-946. [CrossRef] 
102. Yang, M.; Soga, T.; Pollard, P.J. Oncometabolites: Linking altered metabolism with cancer. J. Clin. Investig. 2013, $123,3652-3658$. [CrossRef]

103. Dang, L.; White, D.W.; Gross, S.; Bennett, B.D.; Bittinger, M.A.; Driggers, E.M.; Fantin, V.R.; Jang, H.G.; Jin, S.; Keenan, M.C.; et al. Cancer-associated IDH1 mutations produce 2-hydroxyglutarate. Nature 2009, 462, 739-744. [CrossRef]

104. Ward, P.S.; Patel, J.; Wise, D.R.; Abdel-Wahab, O.; Bennett, B.D.; Coller, H.A.; Cross, J.R.; Fantin, V.R.; Hedvat, C.V.; Perl, A.E.; et al. The Common Feature of Leukemia-Associated IDH1 and IDH2 Mutations Is a Neomorphic Enzyme Activity Converting $\alpha$-Ketoglutarate to 2-Hydroxyglutarate. Cancer Cell 2010, 17, 225-234. [CrossRef] [PubMed]

105. Seth Nanda, C.; Venkateswaran, S.V.; Patani, N.; Yuneva, M. Defining a metabolic landscape of tumours: Genome meets metabolism. Br. J. Cancer 2020, 122, 136-149. [CrossRef]

106. Rohle, D.; Popovici-Muller, J.; Palaskas, N.; Turcan, S.; Grommes, C.; Campos, C.; Tsoi, J.; Clark, O.; Oldrini, B.; Komisopoulou, E.; et al. An inhibitor of mutant IDH1 delays growth and promotes differentiation of glioma cells. Science 2013, 340, 626-630. [CrossRef]

107. Wang, F.; Travins, J.; DeLaBarre, B.; Penard-Lacronique, V.; Schalm, S.; Hansen, E.; Straley, K.; Kernytsky, A.; Liu, W.; Gliser, C.; et al. Targeted Inhibition of Mutant IDH2 in Leukemia Cells Induces Cellular Differentiation. Science 2013, 340, 622-626. [CrossRef] [PubMed]

108. Yen, K.; Travins, J.; Wang, F.; David, M.D.; Artin, E.; Straley, K.; Padyana, A.; Gross, S.; Delabarre, B.; Tobin, E.; et al. AG-221, a first-in-class therapy targeting acute myeloid leukemia harboring oncogenic IDH2 mutations. Cancer Discov. 2017, 7, 478-493. [CrossRef]

109. Roboz, G.J.; DiNardo, C.D.; Stein, E.M.; de Botton, S.; Mims, A.S.; Prince, G.T.; Altman, J.K.; Arellano, M.L.; Donnellan, W.; Erba, H.P.; et al. Ivosidenib induces deep durable remissions in patients with newly diagnosed IDH1-mutant acute myeloid leukemia. Blood 2020, 135, 463-471. [CrossRef] [PubMed]

110. DiNardo, C.D.; Stein, E.M.; de Botton, S.; Roboz, G.J.; Altman, J.K.; Mims, A.S.; Swords, R.; Collins, R.H.; Mannis, G.N.; Pollyea, D.A.; et al. Durable Remissions with Ivosidenib in IDH1-Mutated Relapsed or Refractory AML. N. Engl. J. Med. 2018, 378, 2386-2398. [CrossRef] [PubMed]

111. Stein, E.M.; DiNardo, C.D.; Pollyea, D.A.; Fathi, A.T.; Roboz, G.J.; Altman, J.K.; Stone, R.M.; Deangelo, D.J.; Levine, R.L.; Flinn, I.W.; et al. Enasidenib in mutant IDH2 relapsed or refractory acute myeloid leukemia. Blood 2017, 130, 722-731. [CrossRef]

112. Golub, D.; Iyengar, N.; Dogra, S.; Wong, T.; Bready, D.; Tang, K.; Modrek, A.S.; Placantonakis, D.G. Mutant isocitrate dehydrogenase inhibitors as targeted cancer therapeutics. Front. Oncol. 2019, 9, 417. [CrossRef]

113. Konteatis, Z.; Artin, E.; Nicolay, B.; Straley, K.; Padyana, A.K.; Jin, L.; Chen, Y.; Narayaraswamy, R.; Tong, S.; Wang, F.; et al. Vorasidenib (AG-881): A First-in-Class, Brain-Penetrant Dual Inhibitor of Mutant IDH1 and 2 for Treatment of Glioma. ACS Med. Chem. Lett. 2020, 11, 101-107. [CrossRef] [PubMed]

114. Schumacher, T.; Bunse, L.; Pusch, S.; Sahm, F.; Wiestler, B.; Quandt, J.; Menn, O.; Osswald, M.; Oezen, I.; Ott, M.; et al. A vaccine targeting mutant IDH1 induces antitumour immunity. Nature 2014, 512, 324-327. [CrossRef]

115. Platten, M.; Bunse, L.; Wick, A.; Bunse, T.; Le Cornet, L.; Harting, I.; Sahm, F.; Sanghvi, K.; Tan, C.L.; Poschke, I.; et al. A vaccine targeting mutant IDH1 in newly diagnosed glioma. Nature 2021, 12, 463-468. [CrossRef] [PubMed]

116. Ho, P.C.; Bihuniak, J.D.; MacIntyre, A.N.; Staron, M.; Liu, X.; Amezquita, R.; Tsui, Y.C.; Cui, G.; Micevic, G.; Perales, J.C.; et al. Phosphoenolpyruvate Is a Metabolic Checkpoint of Anti-tumor T Cell Responses. Cell 2015, 162, 1217-1228. [CrossRef]

117. Chang, C.H.; Qiu, J.; O’Sullivan, D.; Buck, M.D.; Noguchi, T.; Curtis, J.D.; Chen, Q.; Gindin, M.; Gubin, M.M.; Van Der Windt, G.J.W.; et al. Metabolic Competition in the Tumor Microenvironment Is a Driver of Cancer Progression. Cell 2015, 162, 1229-1241. [CrossRef]

118. Cascone, T.; McKenzie, J.A.; Mbofung, R.M.; Punt, S.; Wang, Z.; Xu, C.; Williams, L.J.; Wang, Z.; Bristow, C.A.; Carugo, A.; et al. Increased Tumor Glycolysis Characterizes Immune Resistance to Adoptive T Cell Therapy. Cell Metab. 2018, 27, 977-987.e4. [CrossRef] [PubMed]

119. Reinfeld, B.I.; Madden, M.Z.; Wolf, M.M.; Chytil, A.; Bader, J.E.; Patterson, A.R.; Sugiura, A.; Cohen, A.S.; Ali, A.; Do, B.T.; et al. Cell-programmed nutrient partitioning in the tumour microenvironment. Nature 2021, 593, 282-288. [CrossRef]

120. Sullivan, M.R.; Danai, L.V.; Lewis, C.A.; Chan, S.H.; Gui, D.Y.; Kunchok, T.; Dennstedt, E.A.; Vander Heiden, M.G.; Muir, A. Quantification of microenvironmental metabolites in murine cancers reveals determinants of tumor nutrient availability. eLife 2019, 8, 1-27. [CrossRef]

121. Kumar, V.; Patel, S.; Tcyganov, E.; Gabrilovich, D.I. The Nature of Myeloid-Derived Suppressor Cells in the Tumor Microenvironment. Trends Immunol. 2016, 37, 208-220. [CrossRef]

122. Rodriguez, P.C.; Quiceno, D.G.; Zabaleta, J.; Ortiz, B.; Zea, A.H.; Piazuelo, M.B.; Delgado, A.; Correa, P.; Brayer, J.; Sotomayor, E.M.; et al. Arginase I Production in the Tumor Microenvironment by Mature Myeloid Cells Inhibits T-Cell Receptor Expression and Antigen-Specific T-Cell Responses Arginase I Production in the Tumor Microenvironment by Mature Myeloid Cells Inhibits T-Cell Receptor Expr. Cancer Res. 2004, 64, 5839-5849. [CrossRef]

123. Srivastava, M.K.; Sinha, P.; Clements, V.K.; Rodriguez, P.; Ostrand-Rosenberg, S. Myeloid-derived suppressor cells inhibit T-cell activation by depleting cystine and cysteine. Cancer Res. 2010, 70, 68-77. [CrossRef]

124. Yu, J.; Du, W.; Yan, F.; Wang, Y.; Li, H.; Cao, S.; Yu, W.; Shen, C.; Liu, J.; Ren, X. Myeloid-Derived Suppressor Cells Suppress Antitumor Immune Responses through IDO Expression and Correlate with Lymph Node Metastasis in Patients with Breast Cancer. J. Immunol. 2013, 190, 3783-3797. [CrossRef] 
125. Munn, D.H.; Shafizadeh, E.; Attwood, J.T.; Bondarev, I.; Pashine, A.; Mellor, A.L. Inhibition of T Cell Proliferation by Macrophage Tryptophan Catabolism. J. Exp. Med. 1999, 189, 1363-1372. [CrossRef] [PubMed]

126. Pilotte, L.; Larrieu, P.; Stroobant, V.; Colau, D.; Dolušić, E.; Frédérick, R.; De Plaen, E.; Uyttenhove, C.; Wouters, J.; Masereel, B.; et al. Reversal of tumoral immune resistance by inhibition of tryptophan 2,3-dioxygenase. Proc. Natl. Acad. Sci. USA 2012, 109, 2497-2502. [CrossRef] [PubMed]

127. Opitz, C.A.; Litzenburger, U.M.; Sahm, F.; Ott, M.; Tritschler, I.; Trump, S.; Schumacher, T.; Jestaedt, L.; Schrenk, D.; Weller, M.; et al. An endogenous tumour-promoting ligand of the human aryl hydrocarbon receptor. Nature 2011, 478, 197-203. [CrossRef]

128. Rodriguez, P.C.; Quiceno, D.G.; Ochoa, A.C. L-arginine availability regulates T-lymphocyte cell-cycle progression. Blood J. 2007, 109, 1568-1574. [CrossRef] [PubMed]

129. Steggerda, S.M.; Bennett, M.K.; Chen, J.; Emberley, E.; Huang, T.; Janes, J.R.; Li, W.; MacKinnon, A.L.; Makkouk, A.; Marguier, G.; et al. Inhibition of arginase by CB-1158 blocks myeloid cell-mediated immune suppression in the tumor microenvironment. $J$. Immunother. Cancer 2017, 5, 1-18. [CrossRef]

130. Mezrich, J.D.; Fechner, J.H.; Zhang, X.; Johnson, B.P.; Burlingham, W.J.; Bradfield, C.A. An Interaction between Kynurenine and the Aryl Hydrocarbon Receptor Can Generate Regulatory T Cells. J. Immunol. 2010, 185, 3190-3198. [CrossRef]

131. Curti, A.; Pandolfi, S.; Valzasina, B.; Aluigi, M.; Isidori, A.; Ferri, E.; Salvestrini, V.; Bonanno, G.; Rutella, S.; Durelli, I.; et al. Modulation of tryptophan catabolism by human leukemic cells results in the conversion of CD25- into CD25 $5^{+} \mathrm{T}$ regulatory cells. Blood 2007, 109, 2871-2877. [CrossRef] [PubMed]

132. Nguyen, N.T.; Kimura, A.; Nakahama, T.; Chinen, I.; Masuda, K.; Nohara, K.; Fujii-Kuriyama, Y.; Kishimoto, T. Aryl hydrocarbon receptor negatively regulates dendritic cell immunogenicity via a kynurenine-dependent mechanism. Proc. Natl. Acad. Sci. USA 2010, 107, 19961-19966. [CrossRef]

133. Spranger, S.; Koblish, H.K.; Horton, B.; Scherle, P.A.; Newton, R.; Gajewski, T.F. Mechanism of tumor rejection with doublets of CTLA-4, PD-1/PD-L1, or IDO blockade involves restored IL-2 production and proliferation of CD8+ T cells directly within the tumor microenvironment. J. Immunother. Cancer 2014, 2, 1-14. [CrossRef] [PubMed]

134. Wainwright, D.A.; Chang, A.L.; Dey, M.; Balyasnikova, I.V.; Kim, C.K.; Tobias, A.; Cheng, Y.; Kim, J.W.; Qiao, J.; Zhang, L.; et al. Durable therapeutic efficacy utilizing combinatorial blockade against IDO, CTLA-4, and PD-L1 in mice with brain tumors. Clin. Cancer Res. 2014, 20, 5290-5301. [CrossRef]

135. Holmgaard, R.B.; Zamarin, D.; Munn, D.H.; Wolchok, J.D.; Allison, J.P. Indoleamine 2,3-dioxygenase is a critical resistance mechanism in antitumor T cell immunotherapy targeting CTLA-4. J. Exp. Med. 2013, 210, 1389-1402. [CrossRef]

136. Schramme, F.; Crosignani, S.; Frederix, K.; Hoffmann, D.; Pilotte, L.; Stroobant, V.; Preillon, J.; Driessens, G.; van den Eynde, B.J. Inhibition of tryptophan-dioxygenase activity increases the antitumor efficacy of immune checkpoint inhibitors. Cancer Immunol. Res. 2020, 8, 32-45. [CrossRef]

137. Cheong, J.E.; Sun, L. Targeting the IDO1/TDO2-KYN-AhR Pathway for Cancer Immunotherapy-Challenges and Opportunities. Trends Pharmacol. Sci. 2017, 39, 1-19. [CrossRef]

138. Long, G.V.; Dummer, R.; Hamid, O.; Gajewski, T.F.; Caglevic, C.; Dalle, S.; Arance, A.; Carlino, M.S.; Grob, J.J.; Kim, T.M.; et al. Epacadostat plus pembrolizumab versus placebo plus pembrolizumab in patients with unresectable or metastatic melanoma (ECHO-301/KEYNOTE-252): A phase 3, randomised, double-blind study. Lancet Oncol. 2019, 20, 1083-1097. [CrossRef]

139. Friedrich, M.; Sankowski, R.; Bunse, L.; Kilian, M.; Green, E.; Ramallo Guevara, C.; Pusch, S.; Poschet, G.; Sanghvi, K.; Hahn, M.; et al. Tryptophan metabolism drives dynamic immunosuppressive myeloid states in IDH-mutant gliomas. Nat. Cancer 2021. [CrossRef]

140. Zhang, L.; Sorensen, M.D.; Kristensen, B.W.; Reifenberger, G.; McIntyre, T.M.; Lin, F. D-2-hydroxyglutarate is an intercellular mediator in IDH-mutant gliomas inhibiting complement and T cells. Clin. Cancer Res. 2018, 24, 5381-5391. [CrossRef]

141. Kohanbash, G.; Carrera, D.A.; Shrivastav, S.; Ahn, B.J.; Jahan, N.; Mazor, T.; Chheda, Z.S.; Downey, K.M.; Watchmaker, P.B.; Beppler, C.; et al. Isocitrate dehydrogenase mutations suppress STAT1 and CD8 ${ }^{+} \mathrm{T}$ cell accumulation in gliomas. J. Clin. Investig. 2017, 127, 1425-1437. [CrossRef]

142. Bunse, L.; Pusch, S.; Bunse, T.; Sahm, F.; Sanghvi, K.; Friedrich, M.; Alansary, D.; Sonner, J.K.; Green, E.; Deumelandt, K.; et al. Suppression of antitumor T cell immunity by the oncometabolite (R)-2-hydroxyglutarate. Nat. Med. 2018, 24, 1192-1203. [CrossRef]

143. Blay, J.; White, T.; Hoskin, D. The Extracellular Fluid of Solid Carcinomas Contains Immunosuppressive Concentrations of Adenosine. Cancer Res. 1997, 57, 2602-2605.

144. Ohta, A.; Gorelik, E.; Prasad, S.J.; Ronchese, F.; Lukashev, D.; Wong, M.K.K.; Huang, X.; Caldwell, S.; Liu, K.; Smith, P.; et al. A2A adenosine receptor protects tumors from antitumor T cells. Proc. Natl. Acad. Sci. USA 2006, 103, 13132-13137. [CrossRef] [PubMed]

145. Antonioli, L.; Blandizzi, C.; Pacher, P.; Haskó, G. Immunity, inflammation and cancer: A leading role for adenosine. Nat. Rev. Cancer 2013, 13, 842-857. [CrossRef] [PubMed]

146. Deaglio, S.; Dwyer, K.M.; Gao, W.; Friedman, D.; Usheva, A.; Erat, A.; Chen, J.F.; Enjyoji, K.; Linden, J.; Oukka, M.; et al. Adenosine generation catalyzed by CD39 and CD73 expressed on regulatory T cells mediates immune suppression. J. Exp. Med. 2007, 204, 1257-1265. [CrossRef] [PubMed] 
147. Jin, D.; Fan, J.; Wang, L.; Thompson, L.F.; Liu, A.; Daniel, B.J.; Shin, T.; Curiel, T.J.; Zhang, B. CD73 on tumor cells impairs antitumor T-cell responses: A novel mechanism of tumor-induced immune suppression. Cancer Res. 2010, 70, $2245-2255$. [CrossRef]

148. Kobie, J.J.; Shah, P.R.; Yang, L.; Rebhahn, J.A.; Fowell, D.J.; Mosmann, T.R. T Regulatory and Primed Uncommitted CD4 T Cells Express CD73, Which Suppresses Effector CD4 T Cells by Converting 5'-Adenosine Monophosphate to Adenosine. J. Immunol. 2006, 177, 6780-6786. [CrossRef] [PubMed]

149. Clayton, A.; Al-Taei, S.; Webber, J.; Mason, M.D.; Tabi, Z. Cancer Exosomes Express CD39 and CD73, Which Suppress T Cells through Adenosine Production. J. Immunol. 2011, 187, 676-683. [CrossRef] [PubMed]

150. Ryzhov, S.; Novitskiy, S.V.; Goldstein, A.E.; Biktasova, A.; Blackburn, M.R.; Biaggioni, I.; Dikov, M.M.; Feoktistov, I. Adenosinergic Regulation of the Expansion and Immunosuppressive Activity of CD11b + Gr1 + Cells. J. Immunol. 2011, 187, 6120-6129. [CrossRef]

151. Raskovalova, T.; Huang, X.; Sitkovsky, M.; Zacharia, L.C.; Jackson, E.K.; Gorelik, E. G s Protein-Coupled Adenosine Receptor Signaling and Lytic Function of Activated NK Cells. J. Immunol. 2005, 175, 4383-4391. [CrossRef]

152. Mandapathil, M.; Hilldorfer, B.; Szczepanski, M.J.; Czystowska, M.; Szajnik, M.; Ren, J.; Lang, S.; Jackson, E.K.; Gorelik, E.; Whiteside, T.L. Generation and accumulation of immunosuppressive adenosine by human $\mathrm{CD} 44^{+} \mathrm{CD} 25^{\text {high }} \mathrm{FOXP}{ }^{3+}$ regulatory T Cells. J. Biol. Chem. 2010, 285, 7176-7186. [CrossRef]

153. Raskovalova, T.; Lokshin, A.; Huang, X.; Su, Y.; Mandic, M.; Zarour, H.M.; Jackson, E.K.; Gorelik, E. Inhibition of cytokine production and cytotoxic activity of human antimelanoma specific $\mathrm{CD}^{8+}$ and $\mathrm{CD}^{4+} \mathrm{T}$ lymphocytes by adenosine-protein kinase $\mathrm{A}$ type I signaling. Cancer Res. 2007, 67, 5949-5956. [CrossRef]

154. Huang, S.; Apasov, S.; Koshiba, M.; Sitkovsky, M. Role of A2a extracellular adenosine receptor-mediated signaling in adenosinemediated inhibition of T-cell activation and expansion. Blood 1997, 90, 1600-1610. [CrossRef]

155. Zarek, P.E.; Huang, C.T.; Lutz, E.R.; Kowalski, J.; Horton, M.R.; Linden, J.; Drake, C.G.; Powell, J.D. A2A receptor signaling promotes peripheral tolerance by inducing T-cell anergy and the generation of adaptive regulatory T cells. Blood 2008, 111, 251-259. [CrossRef]

156. Stagg, J.; Divisekera, U.; McLaughlin, N.; Sharkey, J.; Pommey, S.; Denoyer, D.; Dwyer, K.M.; Smyth, M.J. Anti-CD73 antibody therapy inhibits breast tumor growth and metastasis. Proc. Natl. Acad. Sci. USA 2010, 107, 1547-1552. [CrossRef]

157. Perrot, I.; Michaud, H.A.; Giraudon-Paoli, M.; Augier, S.; Docquier, A.; Gros, L.; Courtois, R.; Déjou, C.; Jecko, D.; Becquart, O.; et al. Blocking Antibodies Targeting the CD39/CD73 Immunosuppressive Pathway Unleash Immune Responses in Combination Cancer Therapies. Cell Rep. 2019, 27, 2411-2425.e9. [CrossRef]

158. Young, A.; Ngiow, S.F.; Barkauskas, D.S.; Sult, E.; Hay, C.; Blake, S.J.; Huang, Q.; Liu, J.; Takeda, K.; Teng, M.W.L.; et al. Co-inhibition of CD73 and A2AR Adenosine Signaling Improves Anti-tumor Immune Responses. Cancer Cell 2016, 30, $391-403$. [CrossRef] [PubMed]

159. Willingham, S.B.; Ho, P.Y.; Hotson, A.; Hill, C.; Piccione, E.C.; Hsieh, J.; Liu, L.; Buggy, J.J.; McCaffery, I.; Miller, R.A. A2AR antagonism with CPI-444 induces antitumor responses and augments efficacy to anti-PD-(L)1 and anti-CTLA-4 in preclinical models. Cancer Immunol. Res. 2018, 6, 1136-1149. [CrossRef] [PubMed]

160. Li, X.Y.; Moesta, A.K.; Xiao, C.; Nakamura, K.; Casey, M.; Zhang, H.; Madore, J.; Lepletier, A.; Aguilera, A.R.; Sundarrajan, A.; et al. Targeting CD39 in cancer reveals an extracellular ATP-and inflammasome-driven tumor immunity. Cancer Discov. 2019, 9, 1754-1773. [CrossRef] [PubMed]

161. Yan, J.; Li, X.Y.; Aguilera, A.R.; Xiao, C.; Jacoberger-Foissac, C.; Nowlan, B.; Robson, S.C.; Beers, C.; Moesta, A.K.; Geetha, N.; et al. Control of metastases via myeloid CD39 and NK cell effector function. Cancer Immunol. Res. 2020, 8, 356-367. [CrossRef]

162. Allard, B.; Allard, D.; Buisseret, L.; Stagg, J. The adenosine pathway in immuno-oncology. Nat. Rev. Clin. Oncol. 2020, 17, 611-629. [CrossRef] [PubMed]

163. Angelin, A.; Gil-de-Gómez, L.; Dahiya, S.; Jiao, J.; Guo, L.; Levine, M.H.; Wang, Z.; Quinn, W.J.; Kopinski, P.K.; Wang, L.; et al. Foxp3 Reprograms T Cell Metabolism to Function in Low-Glucose, High-Lactate Environments. Cell Metab. 2017, 25, 1282-1293.e7. [CrossRef]

164. Quinn, W.J.; Jiao, J.; TeSlaa, T.; Stadanlick, J.; Wang, Z.; Wang, L.; Akimova, T.; Angelin, A.; Schäfer, P.M.; Cully, M.D.; et al. Lactate Limits T Cell Proliferation via the NAD $(\mathrm{H})$ Redox State. Cell Rep. 2020, 33, 108500. [CrossRef]

165. Wagner, M.; Ealey, K.N.; Tetsu, H.; Kiniwa, T.; Motomura, Y.; Moro, K.; Koyasu, S. Tumor-Derived Lactic Acid Contributes to the Paucity of Intratumoral ILC2s. Cell Rep. 2020, 30, 2743-2757.e5. [CrossRef] [PubMed]

166. Brand, A.; Singer, K.; Koehl, G.E.; Kolitzus, M.; Schoenhammer, G.; Thiel, A.; Matos, C.; Bruss, C.; Klobuch, S.; Peter, K.; et al. LDHA-Associated Lactic Acid Production Blunts Tumor Immunosurveillance by T and NK Cells. Cell Metab. 2016, $24,657-671$. [CrossRef] [PubMed]

167. Hermans, D.; Gautam, S.; García-Cañaveras, J.C.; Gromer, D.; Mitra, S.; Spolski, R.; Li, P.; Christensen, S.; Nguyen, R.; Lin, J.X.; et al. Lactate dehydrogenase inhibition synergizes with IL-21 to promote $\mathrm{CD}^{8+} \mathrm{T}$ cell stemness and antitumor immunity. Proc. Natl. Acad. Sci. USA 2020, 117, 6047-6055. [CrossRef]

168. Ulanovskaya, O.A.; Zuhl, A.M.; Cravatt, B.F. NNMT promotes epigenetic remodeling in cancer by creating a metabolic methylation sink. Nat. Chem. Biol. 2013, 9, 300-306. [CrossRef] 
169. Eckert, M.A.; Coscia, F.; Chryplewicz, A.; Chang, J.W.; Hernandez, K.M.; Pan, S.; Tienda, S.M.; Nahotko, D.A.; Li, G.; Blaženović, I.; et al. Proteomics reveals NNMT as a master metabolic regulator of cancer-associated fibroblasts. Nature 2019, 569, 723-728. [CrossRef]

170. Kilgour, M.K.; MacPherson, S.; Zacharias, L.G.; Ellis, A.E.; Sheldon, R.D.; Liu, E.Y.; Keyes, S.; Pauly, B.; Carleton, G.; Allard, B.; et al. 1-Methylnicotinamide is an immune regulatory metabolite in human ovarian cancer. Sci. Adv. 2021, 7, 1-15. [CrossRef]

171. Gao, Y.; Van Haren, M.J.; Moret, E.E.; Rood, J.J.M.; Sartini, D.; Salvucci, A.; Emanuelli, M.; Craveur, P.; Babault, N.; Jin, J.; et al. Bisubstrate inhibitors of nicotinamide N-methyltransferase (NNMT) with enhanced activity. J. Med. Chem. 2019, 62, 6597-6614. [CrossRef] [PubMed]

172. Neelakantan, H.; Wang, H.Y.; Vance, V.; Hommel, J.D.; McHardy, S.F.; Watowich, S.J. Structure-Activity Relationship for Small Molecule Inhibitors of Nicotinamide N-Methyltransferase. J. Med. Chem. 2017, 60, 5015-5028. [CrossRef]

173. Policarpo, R.L.; Decultot, L.; May, E.; Kuzmič, P.; Carlson, S.; Huang, D.; Chu, V.; Wright, B.A.; Dhakshinamoorthy, S.; Kannt, A.; et al. High-Affinity Alkynyl Bisubstrate Inhibitors of Nicotinamide N-Methyltransferase (NNMT). J. Med. Chem. 2019, 62, 9837-9873. [CrossRef] [PubMed]

174. Chen, D.; Li, L.; Diaz, K.; Iyamu, I.D.; Yadav, R.; Noinaj, N.; Huang, R. Novel Propargyl-Linked Bisubstrate Analogues as Tight-Binding Inhibitors for Nicotinamide N-Methyltransferase. J. Med. Chem. 2019, 62, 10783-10797. [CrossRef] [PubMed]

175. Baumann, T.; Dunkel, A.; Schmid, C.; Schmitt, S.; Hiltensperger, M.; Lohr, K.; Laketa, V.; Donakonda, S.; Ahting, U.; LorenzDepiereux, B.; et al. Regulatory myeloid cells paralyze T cells through cell-cell transfer of the metabolite methylglyoxal. Nat. Immunol. 2020, 21, 555-566. [CrossRef]

176. Gambhir, S.S. Molecular imaging of cancer with positron emission tomography. Nat. Rev. Cancer 2002, 2, 683-693. [CrossRef]

177. Venneti, S.; Dunphy, M.P.; Zhang, H.; Pitter, K.L.; Zanzonico, P.; Campos, C.; Carlin, S.D.; La Rocca, G.; Lyashchenko, S.; Ploessl, K.; et al. Glutamine-based PET imaging facilitates enhanced metabolic evaluation of gliomas in vivo. Sci. Transl. Med. $2015,7$. [CrossRef] [PubMed]

178. Oyama, N.; Miller, T.R.; Dehdashti, F.; Siegel, B.A.; Fischer, K.C.; Michalski, J.M.; Kibel, A.S.; Andriole, G.L.; Picus, J.; Welch, M.J. 11C-acetate PET imaging of prostate cancer: Detection of recurrent disease at PSA relapse. J. Nucl. Med. 2003, 44, 549-555. [PubMed]

179. Ho, C.L.; Yu, S.C.H.; Yeung, D.W.C. 11C-acetate PET imaging in hepatocellular carcinoma and other liver masses. J. Nucl. Med. 2003, 44, 213-221.

180. Lieberman, B.P.; Ploessl, K.; Wang, L.; Qu, W.; Zha, Z.; Wise, D.R.; Chodosh, L.A.; Belka, G.; Thompson, C.B.; Kung, H.F. PET Imaging of Glutaminolysis in Tumors by 18F-(2S,4R)4-Fluoroglutamine. J. Nucl. Med. 2011, 52, 1947-1955. [CrossRef]

181. Zhou, R.; Pantel, A.R.; Li, S.; Lieberman, B.P.; Ploessl, K.; Choi, H.; Blankemeyer, E.; Lee, H.; Kung, H.F.; Mach, R.H.; et al. $18 \mathrm{~F}](2 \mathrm{~S}, 4 \mathrm{R}) 4$-fluoroglutamine PET detects glutamine pool size changes in triple-negative breast cancer in response to glutaminase inhibition. Cancer Res. 2017, 77, 1476-1484. [CrossRef]

182. Choi, C.; Ganji, S.K.; DeBerardinis, R.J.; Hatanpaa, K.J.; Rakheja, D.; Kovacs, Z.; Yang, X.L.; Mashimo, T.; Raisanen, J.M.; MarinValencia, I.; et al. 2-Hydroxyglutarate detection by magnetic resonance spectroscopy in IDH-mutated patients with gliomas. Nat. Med. 2012, 18, 624-629. [CrossRef]

183. Andronesi, O.C.; Kim, G.S.; Gerstner, E.; Batchelor, T.; Tzika, A.A.; Fantin, V.R.; Vander Heiden, M.G.; Sorensen, A.G. Detection of 2-Hydroxyglutarate in IDH-Mutated Glioma Patients by In Vivo Spectral-Editing and 2D Correlation Magnetic Resonance Spectroscopy. Sci. Transl. Med. 2012, 4, 116ra4. [CrossRef]

184. Elkhaled, A.; Jalbert, L.E.; Phillips, J.J.; Yoshihara, H.A.I.; Parvataneni, R.; Srinivasan, R.; Bourne, G.; Berger, M.S.; Chang, S.M.; Cha, S.; et al. Magnetic Resonance of 2-Hydroxyglutarate in IDH1-Mutated Low-Grade Gliomas. Sci. Transl. Med. 2012, 4, 116ra5. [CrossRef] [PubMed]

185. Pope, W.B.; Prins, R.M.; Thomas, M.A.; Nagarajan, R.; Yen, K.E.; Bittinger, M.A.; Salamon, N.; Chou, A.P.; Yong, W.H.; Soto, H.; et al. Non-invasive detection of 2-hydroxyglutarate and other metabolites in IDH1 mutant glioma patients using magnetic resonance spectroscopy. J. Neurooncol. 2012, 107, 197-205. [CrossRef]

186. Ardenkjær-Larsen, J.H.; Fridlund, B.; Gram, A.; Hansson, G.; Hansson, L.; Lerche, M.H.; Servin, R.; Thaning, M.; Golman, K. Increase in signal-to-noise ratio of $>10,000$ times in liquid-state NMR. Proc. Natl. Acad. Sci. USA 2003, 100, 10158-10163. [CrossRef] [PubMed]

187. Nelson, S.J.; Kurhanewicz, J.; Vigneron, D.B.; Larson, P.E.Z.; Harzstark, A.L.; Ferrone, M.; Van Criekinge, M.; Chang, J.W.; Bok, R.; Park, I.; et al. Metabolic Imaging of Patients with Prostate Cancer Using Hyperpolarized [1-13 C] Pyruvate. Sci. Transl. Med. 2013, 5, 198ra108. [CrossRef]

188. Day, S.E.; Kettunen, M.I.; Gallagher, F.A.; Hu, D.E.; Lerche, M.; Wolber, J.; Golman, K.; Ardenkjaer-Larsen, J.H.; Brindle, K.M. Detecting tumor response to treatment using hyperpolarized 13C magnetic resonance imaging and spectroscopy. Nat. Med. 2007, 13, 1382-1387. [CrossRef]

189. Scroggins, B.T.; Matsuo, M.; White, A.O.; Saito, K.; Munasinghe, J.P.; Sourbier, C.; Yamamoto, K.; Diaz, V.; Takakusagi, Y.; Ichikawa, K.; et al. Hyperpolarized [1-13C]-pyruvate magnetic resonance spectroscopic imaging of prostate cancer In vivo predicts efficacy of targeting the warburg effect. Clin. Cancer Res. 2018, 24, 3137-3148. [CrossRef]

190. Dutta, P.; Le, A.; Vander Jagt, D.L.; Tsukamoto, T.; Martinez, G.V.; Dang, C.V.; Gillies, R.J. Evaluation of LDH-A and glutaminase inhibition in vivo by hyperpolarized 13C-pyruvate magnetic resonance spectroscopy of tumors. Cancer Res. 2013, 73, 4190-4195. [CrossRef] [PubMed] 
191. Rodrigues, T.B.; Serrao, E.M.; Kennedy, B.W.C.; Hu, D.E.; Kettunen, M.I.; Brindle, K.M. Magnetic resonance imaging of tumor glycolysis using hyperpolarized 13 C-labeled glucose. Nat. Med. 2014, 20, 93-97. [CrossRef]

192. Chaumeil, M.M.; Larson, P.E.Z.; Yoshihara, H.A.I.; Danforth, O.M.; Vigneron, D.B.; Nelson, S.J.; Pieper, R.O.; Phillips, J.J.; Ronen, S.M. Non-invasive in vivo assessment of IDH1 mutational status in glioma. Nat. Commun. 2013, 4, 1-12. [CrossRef]

193. Salamanca-Cardona, L.; Shah, H.; Poot, A.J.; Correa, F.M.; Di Gialleonardo, V.; Lui, H.; Miloushev, V.Z.; Granlund, K.L.; Tee, S.S.; Cross, J.R.; et al. In Vivo Imaging of Glutamine Metabolism to the Oncometabolite 2-Hydroxyglutarate in IDH1/2 Mutant Tumors. Cell Metab. 2017, 26, 830-841.e3. [CrossRef] [PubMed]

194. Sreekumar, A.; Poisson, L.M.; Rajendiran, T.M.; Khan, A.P.; Cao, Q.; Yu, J.; Laxman, B.; Mehra, R.; Lonigro, R.J.; Li, Y.; et al. Metabolomic profiles delineate potential role for sarcosine in prostate cancer progression. Nature 2009, 457, 910-914. [CrossRef] [PubMed]

195. Struys, E.A.; Heijboer, A.C.; Van Moorselaar, J.; Jakobs, C.; Blankenstein, M.A. Serum sarcosine is not a marker for prostate cancer. Ann. Clin. Biochem. 2010, 47, 282. [CrossRef]

196. Ankerst, D.P.; Liss, M.; Zapata, D.; Hoefler, J.; Thompson, I.M.; Leach, R.J. A case control study of sarcosine as an early prostate cancer detection biomarker Urological oncology. BMC Urol. 2015, 15, 1-4. [CrossRef] [PubMed]

197. Fan, J.; Teng, X.; Liu, L.; Mattaini, K.R.; Looper, R.E.; Vander Heiden, M.G.; Rabinowitz, J.D. Human phosphoglycerate dehydrogenase produces the oncometabolite D-2-hydroxyglutarate. ACS Chem. Biol. 2015, 10, 510-516. [CrossRef]

198. Intlekofer, A.M.; DeMatteo, R.G.; Venneti, S.; Finley, L.W.S.; Lu, C.; Judkins, A.R.; Rustenburg, A.S.; Grinaway, P.B.; Chodera, J.D.; Cross, J.R.; et al. Hypoxia Induces Production of L-2-Hydroxyglutarate. Cell Metab. 2015, 22, 304-311. [CrossRef]

199. Intlekofer, A.M.; Wang, B.; Liu, H.; Shah, H.; Carmona-Fontaine, C.; Rustenburg, A.S.; Salah, S.; Gunner, M.R.; Chodera, J.D.; Cross, J.R.; et al. L-2-Hydroxyglutarate production arises from noncanonical enzyme function at acidic pH. Nat. Chem. Biol. 2017, 13, 494-500. [CrossRef]

200. DiNardo, C.D.; Propert, K.J.; Loren, A.W.; Paietta, E.; Sun, Z.; Levine, R.L.; Straley, K.S.; Yen, K.; Patel, J.P.; Agresta, S.; et al. Serum 2-hydroxyglutarate levels predict isocitrate dehydrogenase mutations and clinical outcome in acute myeloid leukemia. Blood 2013, 121, 4917-4924. [CrossRef]

201. Gross, S.; Cairns, R.A.; Minden, M.D.; Driggers, E.M.; Bittinger, M.A.; Jang, H.G.; Sasaki, M.; Jin, S.; Schenkein, D.P.; Su, S.M.; et al. Cancer-associated metabolite 2-hydroxyglutarate accumulates in acute myelogenous leukemia with isocitrate dehydrogenase 1 and 2 mutations. J. Exp. Med. 2010, 207, 339-344. [CrossRef]

202. Janin, M.; Mylonas, E.; Saada, V.; Micol, J.B.; Renneville, A.; Quivoron, C.; Koscielny, S.; Scourzic, L.; Forget, S.; Pautas, C.; et al. Serum 2-hydroxyglutarate production in IDH1- And IDH2-mutated de novo acute myeloid leukemia: A study by the acute leukemia french association group. J. Clin. Oncol. 2014, 32, 297-305. [CrossRef] [PubMed]

203. Fathi, A.T.; Sadrzadeh, H.; Borger, D.R.; Ballen, K.K.; Amrein, P.C.; Attar, E.C.; Foster, J.; Burke, M.; Lopez, H.U.; Matulis, C.R.; et al. Prospective serial evaluation of 2-hydroxyglutarate, during treatment of newly diagnosed acute myeloid leukemia, to assess disease activity and therapeutic response. Blood 2012, 120, 4649-4652. [CrossRef] [PubMed]

204. Opitz, C.A.; Somarribas Patterson, L.F.; Mohapatra, S.R.; Dewi, D.L.; Sadik, A.; Platten, M.; Trump, S. The therapeutic potential of targeting tryptophan catabolism in cancer. Br. J. Cancer 2020, 122, 30-44. [CrossRef]

205. Liu, X.; Shin, N.; Koblish, H.K.; Yang, G.; Wang, Q.; Wang, K.; Leffet, L.; Hansbury, M.J.; Thomas, B.; Rupar, M.; et al. Selective inhibition of IDO1 effectively regulates mediators of antitumor immunity. Blood 2010, 115, 3520-3530. [CrossRef] [PubMed]

206. Liu, Y.; Liang, X.; Dong, W.; Fang, Y.; Lv, J.; Zhang, T.; Fiskesund, R.; Xie, J.; Liu, J.; Yin, X.; et al. Tumor-Repopulating Cells Induce PD-1 Expression in CD8 ${ }^{+}$T Cells by Transferring Kynurenine and AhR Activation. Cancer Cell 2018, 33, 480-494.e7. [CrossRef] [PubMed]

207. Balog, A.; Lin, T.A.; Maley, D.; Gullo-Brown, J.; Kandoussi, E.H.; Zeng, J.; Hunt, J.T. Preclinical characterization of linrodostat mesylate, a novel, potent, and selective oral indoleamine 2,3-dioxygenase 1 inhibitor. Mol. Cancer Ther. 2021, 20, 467-476. [CrossRef] [PubMed]

208. Beatty, G.L.; O’Dwyer, P.J.; Clark, J.; Shi, J.G.; Bowman, K.J.; Scherle, P.A.; Newton, R.C.; Schaub, R.; Maleski, J.; Leopold, L.; et al. First-in-human phase I study of the oral inhibitor of indoleamine 2,3-dioxygenase-1 epacadostat (INCB024360) in patients with advanced solid malignancies. Clin. Cancer Res. 2017, 23, 3269-3276. [CrossRef]

209. Gomes, B.; Driessens, G.; Bartlett, D.; Cai, D.; Cauwenberghs, S.; Crosignani, S.; Dalvie, D.; Denies, S.; Dillon, C.P.; Fantin, V.R.; et al. Characterization of the selective indoleamine 2,3-dioxygenase-1 (IDO1) catalytic inhibitor EOS200271/PF-06840003 supports IDO1 as a critical resistance mechanism to PD-(L)1 blockade therapy. Mol. Cancer Ther. 2018, 17, 2530-2542. [CrossRef] [PubMed]

210. Jung, K.H.; LoRusso, P.; Burris, H.; Gordon, M.; Bang, Y.J.; Hellmann, M.D.; Cervantes, A.; Ochoa de Olza, M.; Marabelle, A.; Stephen Hodi, F.; et al. Phase I study of the indoleamine 2,3-dioxygenase 1 (IDO1) inhibitor navoximod (GDC-0919) administered with PD-L1 inhibitor (atezolizumab) in advanced solid tumors. Clin. Cancer Res. 2019, 25, 3220-3228. [CrossRef]

211. Ghergurovich, J.M.; Lang, J.D.; Levin, M.K.; Briones, N.; Facista, S.J.; Mueller, C.; Cowan, A.J.; McBride, M.J.; San Roman Rodriguez, E.; Killian, A.; et al. Local production of lactate, ribose phosphate, and amino acids by human triple-negative breast cancer. Med 2021, 2, 1-19. [CrossRef]

212. Hensley, C.T.; Faubert, B.; Yuan, Q.; Lev-Cohain, N.; Jin, E.; Kim, J.; Jiang, L.; Ko, B.; Skelton, R.; Loudat, L.; et al. Metabolic Heterogeneity in Human Lung Tumors. Cell 2016, 164, 681-694. [CrossRef] 
213. Courtney, K.D.; Bezwada, D.; Mashimo, T.; Pichumani, K.; Vemireddy, V.; Funk, A.M.; Wimberly, J.; McNeil, S.S.; Kapur, P.; Lotan, Y.; et al. Isotope Tracing of Human Clear Cell Renal Cell Carcinomas Demonstrates Suppressed Glucose Oxidation In Vivo. Cell Metab. 2018, 28, 1-8. [CrossRef] [PubMed]

214. Johnston, K.; Pachnis, P.; Tasdogan, A.; Faubert, B.; Zacharias, L.G.; Vu, H.S.; Rodgers-Augustyniak, L.; Johnson, A.; Huang, F.; Ricciardio, S.; et al. Isotope tracing reveals glycolysis and oxidative metabolism in childhood tumors of multiple histologies. Med 2021, 2, 395-410.e4. [CrossRef] [PubMed]

215. Faubert, B.; Li, K.Y.; Cai, L.; Hensley, C.T.; Kim, J.; Zacharias, L.G.; Yang, C.; Do, Q.N.; Doucette, S.; Burguete, D.; et al. Lactate Metabolism in Human Lung Tumors. Cell 2017, 171, 358-371.e9. [CrossRef]

216. Ignatiadis, M.; Sledge, G.W.; Jeffrey, S.S. Liquid biopsy enters the clinic-Implementation issues and future challenges. Nat. Rev. Clin. Oncol. 2021, 18, 297-312. [CrossRef] 